4

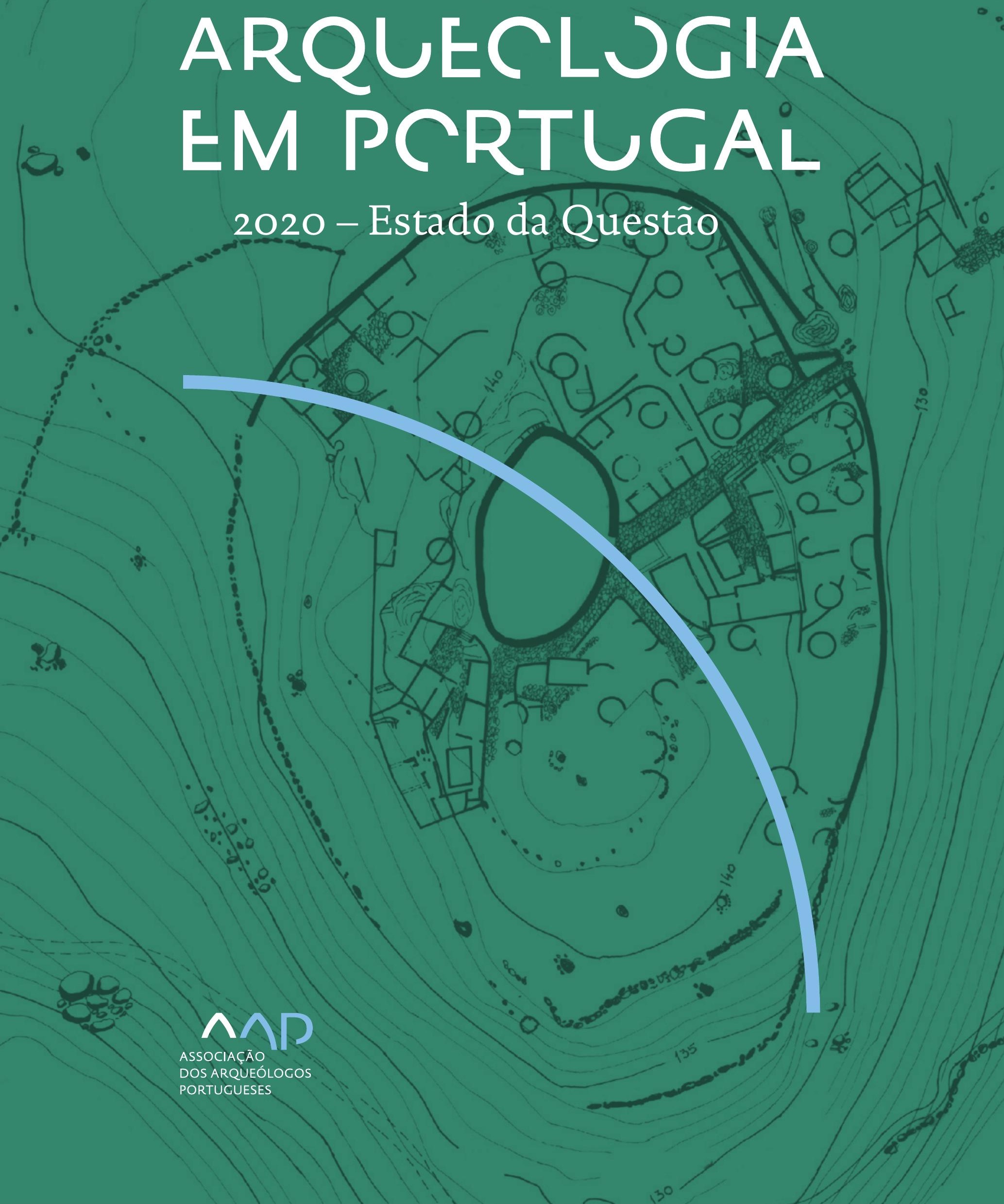


Coordenação editorial: José Morais Arnaud, César Neves e Andrea Martins Design gráfico: Flatland Design

AAP - ISBN: 978-972-9451-89-8

CITCEM - ISBN: 978-989-8970-25-1

Associação dos Arqueólogos Portugueses e CITCEM

Lisboa, 2020

O conteúdo dos artigos é da inteira responsabilidade dos autores. Sendo assim a Associação dos Arqueólogos Portugueses declina qualquer responsabilidade por eventuais equívocos ou questões de ordem ética e legal.

Desenho de capa:

Planta do castro de Monte Mozinho (Museu Municipal de Penafiel).

\section{$\hat{\wedge} \mathrm{P}$}

DOS ARQUEÓLOGOS PORTUGUESES

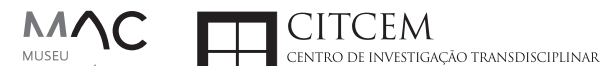
MUSEU
ARQUELLÓGICO
DO CARMO
U.PORTO

FLUP FACULDADE DE LETRAS
UNIVERSIDADE DO PORTO

Apoio

EC para a Ciência 


\section{Índice}

15 Prefácio

José Morais Arnaud

\section{Historiografia e Teoria}

17 Território, comunidade, memória e emoção: a contribuição da história da arqueologia (algumas primeiras e breves reflexões)

Ana Cristina Martins

25 Como descolonizar a arqueologia portuguesa?

Rui Gomes Coelho

41 Arqueologia e Modernidade: uma revisitação pessoal e breve de alguns aspetos da obra homónima de Julian Thomas de 2004

Vítor Oliveira Jorge

57 Dados para a História das Mulheres na Arqueologia portuguesa, dos finais do século XIX aos inícios do século XX: números, nomes e tabelas

Filipa Dimas / Mariana Diniz

73 Retractos da arqueologia portuguesa na imprensa: (in)visibilidades no feminino

Catarina Costeira / Elsa Luís

85 Arqueologia e Arqueólogos no Norte de Portugal Jacinta Bugalhão

101 Vieira Guimarães (1864-1939) e a arqueologia em Tomar: uma abordagem sobre o território e as gentes

João Amendoeira Peixoto / Ana Cristina Martins

115 Os memoráveis? A arqueologia algarvia na imprensa nacional e regional na presente centúria (2001-2019): características, visões do(s) passado(s) e a arqueologia

enquanto marca

Frederico Agosto / João Silva

129 A Evolução da Arqueologia Urbana e a Valorização Patrimonial no Barlavento Algarvio: Os casos de Portimão e Silves

Artur Mateus / Diogo Varandas / Rafael Boavida

\section{Gestão, Valorização e Salvaguarda do Património}

145 O Caderno Reivindicativo e as condições de trabalho em Arqueologia Miguel Rocha / Liliana Matias Carvalho / Regis Barbosa / Mauro Correia / Sara Simões / Jacinta Bugalhão / Sara Brito / Liliana Veríssimo Carvalho / Richard Peace / Pedro Peça / Cézer Santos

155 Os Estudos de Impacte Patrimonial como elemento para uma estratégia sustentável de minimização de impactes no âmbito de reconversões agrícolas Tiago do Pereiro

165 Salvaguarda de Património arqueológico em operações florestais: gestão e sensibilização Filipa Bragança / Gertrudes Zambujo / Sandra Lourenço / Belém Paiva / Carlos Banha / Frederico Tatá Regala / Helena Moura / Jacinta Bugalhão / João Marques / José Correia / Pedro Faria / Samuel Melro

179 Os valores do Património: uma investigação sobre os Sítios Pré-históricos de Arte Rupestre do Vale do Rio Côa e de Siega Verde José Paulo Francisco 
189 Conjugando recursos arqueológicos e naturais para potenciar as visitas ao Geoparque Litoral de Viana do Castelo (Noroeste de Portugal)

Hugo A. Sampaio / Ana M.S. Bettencourt / Susana Marinho / Ricardo Carvalhido

203 Áreas de Potencial Arqueológico na Região do Médio Tejo: Modelo Espacial Preditivo Rita Ferreira Anastácio / Ana Filipa Martins / Luiz Oosterbeek

223 Património Arqueológico e Gestão Territorial: O contributo da Arqueologia para a revisão do PDM de Avis

Ana Cristina Ribeiro

237 A coleção arqueológica do extinto Museu Municipal do Porto - Origens, Percursos e Estudos

Sónia Couto

251 Valpaços - uma nova carta arqueológica

Pedro Pereira / Maria de Fátima Casares Machado

263 Arqueologia na Cidade de Peniche

Adriano Constantino / Luís Rendeiro

273 Arqueologia Urbana: a cidade de Lagos como caso de Estudo Cátia Neto

285 Estratégias de promoção do património cultural subaquático nos Açores. O caso da ilha do Faial

José Luís Neto / José Bettencourt / Luís Borges / Pedro Parreira

297 Carta Arqueológica da Cidade Velha: Uma primeira abordagem

Jaylson Monteiro / Nireide Tavares / Sara da Veiga / Claudino Ramos / Edson Brito /

Carlos Carvalho / Francisco Moreira / Adalberto Tavares

311 Antropologia Virtual: novas metodologias para a análise morfológica e funcional Ricardo Miguel Godinho / Célia Gonçalves

\section{Didáctica da Arqueologia}

327 Como os projetos de Arqueologia podem contribuir para uma comunidade culturalmente mais consciente Alexandra Figueiredo / Claúdio Monteiro / Adolfo Silveira / Ricardo Lopes

337 Educação Patrimonial - Um cidadão esclarecido é um cidadão ativo! Ana Paula Almeida

351 A aproximação da Arqueologia à sala de aula: um caso de estudo no $3^{\circ}$ ciclo do Ensino Básico Luís Serrão Gil

363 Arqueologia 3.o - Pensar e comunicar a Arqueologia para um futuro sustentável Mónica Rolo

377 “Conversa de Arqueólogos" - Divulgar a Arqueologia em tempos de Pandemia Diogo Teixeira Dias

389 Escola Profissional de Arqueologia: desafios e oportunidades Susana Nunes / Dulcineia Pinto / Júlia Silva / Ana Mascarenhas

399 Os Museus de Arqueologia e os Jovens: a oferta educativa para o público adolescente Beatriz Correia Barata / Leonor Medeiros

411 O museu universitário como mediador entre a ciência e a sociedade: o exemplo da secção de arqueologia no Museu de História Natural e da Ciência da Universidade do Porto (MHNC-UP)

Rita Gaspar 
421 Museu de Lanifícios: Real Fábrica de Panos. Atividades no âmbito da Arqueologia Beatriz Correia Barata / Rita Salvado

427 Arqueologia Pública e o caso da localidade da Mata (Torres Novas) Cláudia Manso / Ana Rita Ferreira / Cristiana Ferreira / Vanessa Cardoso Antunes

431 Do sítio arqueológico ao museu: um percurso (também) didático Lídia Fernandes

447 Estão todos convidados para a Festa! E para dançar também... O projecto do Serviço Educativo do Museu Arqueológico do Carmo na $5^{\underline{a}}$ Edição da Festa da Arqueologia Rita Pires dos Santos

459 O “Clã de Carenque”, um projeto didático de arqueologia Eduardo Gonzalez Rocha

469 Mediação cultural: peixe que puxa carroça nas Ruínas Romanas de Troia Inês Vaz Pinto / Ana Patrícia Magalhães / Patrícia Brum / Filipa Santos

481 Didática Arqueológica, experiências do Projeto Mértola Vila Museu Maria de Fátima Palma / Clara Rodrigues / Susana Gómez / Lígia Rafael

\section{Arte Rupestre}

497 Os inventários de arte rupestre em Portugal Mila Simões de Abreu

513 O projeto FIRST-ART - conservação, documentação e gestão das primeiras manifestações de arte rupestre no Sudoeste da Península Ibérica: as grutas do Escoural e Maltravieso Sara Garcês / Hipólito Collado / José Julio García Arranz / Luiz Oosterbeek / António Carlos Silva / Pierluigi Rosina / Hugo Gomes / Anabela Borralheiro Pereira / George Nash / Esmeralda Gomes / Nelson Almeida / Carlos Carpetudo

523 Trabalhos de documentação de arte paleolítica realizados no âmbito do projeto PalæoCôa André Tomás Santos / António Fernando Barbosa / Luís Luís / Marcelo Silvestre / Thierry Aubry

537 Imagens fantasmagóricas, silhuetas elusivas: as figuras humanas na arte do Paleolítico Superior da região do Côa Mário Reis

$55^{1}$ Os motivos zoomórficos representados nas placas de tear de Vila Nova de São Pedro (Azambuja, Portugal) Andrea Martins / César Neves / José M. Arnaud / Mariana Diniz

571 Arte Rupestre do Monte de Góios (Lanhelas, Caminha). Síntese dos resultados dos trabalhos efectuados em 2007-2009 Mário Varela Gomes

599 Gravuras rupestres de barquiformes no Monte de S. Romão, Guimarães, Noroeste de Portugal Daniela Cardoso

613 Círculos segmentados gravados na Bacia do Rio Lima (Noroeste de Portugal): contributos para o seu estudo Diogo Marinho / Ana M.S. Bettencourt / Hugo Aluai Sampaio

631 Equídeos gravados no curso inferior do Rio Mouro, Monção (NW Portugal). Análise preliminar Coutinho, L.M. / Bettencourt, A.M.S / Sampaio, Hugo A.S

645 Paletas na Arte Rupestre do Noroeste de Portugal. Inventário preliminar Bruna Sousa Afonso / Ana M. S. Bettencourt / Hugo A. Sampaio 


\section{Pré-História}

661 O projeto Miño/Minho: balanço de quatro anos de trabalhos arqueológicos Sérgio Monteiro-Rodrigues / João Pedro Cunha-Ribeiro / Eduardo Méndez-Quintas / Carlos Ferreira / Pedro Xavier / José Meireles / Alberto Gomes / Manuel Santonja / Alfredo Pérez-González

677 A ocupação paleolítica da margem esquerda do Baixo Minho: a indústria lítica do sítio de Pedreiras 2 (Monção, Portugal) e a sua integração no contexto regional Carlos Ferreira / João Pedro Cunha-Ribeiro / Sérgio Monteiro-Rodrigues / Eduardo Méndez-Quintas / Pedro Xavier / José Meireles / Alberto Gomes / Manuel Santonja / Alfredo Pérez-González

693 O sítio acheulense do Plistocénico médio da Gruta da Aroeira Joan Daura / Montserrat Sanz / Filipa Rodrigues / Pedro Souto / João Zilhão

703 As sociedades neandertais no Barlavento algarvio: modelos preditivos com recurso aos SIG

Daniela Maio

715 A utilização de quartzo durante o Paleolítico Superior no território dos vales dos rios Vouga e Côa

Cristina Gameiro / Thierry Aubry / Bárbara Costa / Sérgio Gomes / Luís Luís / Carmen Manzano / André Tomás Santos

733 Uma perspetiva diacrónica da ocupação do concheiro do Cabeço da Amoreira (Muge, Portugal) a partir da tecnologia lítica Joana Belmiro / João Cascalheira / Célia Gonçalves

745 Novos dados sobre a Pré-história Antiga no concelho de Palmela. A intervenção arqueológica no sítio do Poceirão I

Michelle Teixeira Santos

757 Problemas em torno de Datas Absolutas Pré-Históricas no Norte do Alentejo Jorge de Oliveira

771 Povoamento pré-histórico nas áreas montanhosas do NO de Portugal: o Abrigo 1 de Vale de Cerdeira Pedro Xavier / José Meireles / Carlos Alves

783 Apreciação do povoamento do Neolítico Inicial na Baixa Bacia do Douro. A Lavra I (Serra da Aboboreira) como caso de estudo Maria de Jesus Sanches

797 O Processo de Neolitização na Plataforma do Mondego: os dados do Sector C do Outeiro dos Castelos de Beijós (Carregal do Sal)

João Carlos de Senna-Martinez / José Manuel Quintã Ventura / Andreia Carvalho / Cíntia Maurício

823 Novos trabalhos na Lapa da Bugalheira (Almonda, Torres Novas) Filipa Rodrigues / Pedro Souto / Artur Ferreira / Alexandre Varanda / Luís Gomes / Helena Gomes / João Zilhão

837 A pedra polida e afeiçoada do sítio do Neolítico médio da Moita do Ourives (Benavente, Portugal)

César Neves

857 Casal do Outeiro (Encarnação, Mafra): novos contributos para o conhecimento do povoamento do Neolítico final na Península de Lisboa.

Cátia Delicado / Carlos Maneira e Costa / Marta Miranda / Ana Catarina Sousa

873 Stresse infantil, morbilidade e mortalidade no sítio arqueológico do Neolítico Final/ Calcolítico ( $4^{\circ}$ e $3^{\circ}$ milénio a.C.) do Monte do Carrascal 2 (Ferreira do Alentejo, Beja) Liliana Matias de Carvalho / Sofia N. Wasterlain 
885 Come together: O Conjunto Megalítico das Motas (Monção, Viana do Castelo) e as expressões Campaniformes do Alto Minho Ana Catarina Basílio / Rui Ramos

899 Trabalhos arqueológicos no sítio Calcolítico da Pedreira do Poio Carla Magalhães / João Muralha / Mário Reis / António Batarda Fernandes

913 O sítio arqueológico de Castanheiro do Vento. Da arquitectura do sítio à arquitectura de um território João Muralha Cardoso

925 Estudo zooarqueológico das faunas do Calcolítico final de Vila Nova de São Pedro (Azambuja, Portugal): Campanhas de 2017 e 2018 Cleia Detry / Ana Catarina Francisco / Mariana Diniz / Andrea Martins / César Neves / José Morais Arnaud

943 As faunas depositadas no Museu Arqueológico do Carmo provenientes de Vila Nova de São Pedro (Azambuja): as campanhas de 1937 a 1967 Ana Catarina Francisco / Cleia Detry / César Neves / Andrea Martins / Mariana Diniz / José Morais Arnaud

959 Análise funcional de material lítico em sílex do castro de Vila Nova de S. Pedro (Azambuja, Portugal): uma primeira abordagem Rafael Lima

971 O recinto da Folha do Ouro 1 (Serpa) no contexto dos recintos de fossos calcolíticos alentejanos

António Carlos Valera / Tiago do Pereiro / Pedro Valério / António M. Monge Soares

\section{Proto-História}

987 Produção de sal marinho na Idade do Bronze do noroeste Português. Alguns dados para uma reflexão

Ana M. S. Bettencourt / Sara Luz / Nuno Oliveira / Pedro P. Simões / Maria Isabel C. Alves / Emílio Abad-Vidal

1001 A estátua-menir do Pedrão ou de São Bartolomeu do Mar (Esposende, noroeste de Portugal) no contexto arqueológico da fachada costeira de entre os rios Neiva e Cávado Ana M. S. Bettencourt / Manuel Santos-Estévez / Pedro Pimenta Simões / Luís Gonçalves

1015 O Castro do Muro (Vandoma/Baltar, Paredes) - notas para uma biografia de ocupação da Idade do Bronze à Idade Média

Maria Antónia D. Silva / Ana M. S. Bettencourt / António Manuel S. P. Silva / Natália Félix

1031 Do Bronze Final à Idade Média - continuidades e hiatos na ocupação de Povoados em Oliveira de Azeméis João Tiago Tavares / Adriaan de Man

1041 As faunas do final da Idade do Bronze no Sul de Portugal: leituras desde o Outeiro do Circo (Beja)

Nelson J. Almeida / Íris Dias / Cleia Detry / Eduardo Porfírio / Miguel Serra

1055 A Espada do Monte das Oliveiras (Serpa) - uma arma do Bronze Pleno do Sudoeste Rui M. G. Monge Soares / Pedro Valério / Mariana Nabais / António M. Monge Soares

1065 São Julião da Branca (Albergaria-a-Velha) - Investigação e valorização de um povoado do Bronze Final

António Manuel S. P. Silva / Paulo A. P. Lemos / Sara Almeida e Silva / Edite Martins de Sá

1083 Do castro de S. João ao Mosteiro de Santa Clara: notícia de uma intervenção arqueológica, em Vila do Conde Rui Pinheiro 
1095 O castro de Ovil (Espinho), um quarto de século de investigação - resultados e questões em aberto

Jorge Fernando Salvador / António Manuel S. P. Silva

1111 O Castro de Salreu (Estarreja), um povoado proto-histórico no litoral do Entre Douro e Vouga

Sara Almeida e Silva / António Manuel S. P. Silva / Paulo A. P. Lemos / Edite Martins de Sá

1127 Castro de Nossa Senhora das Necessidades (Sernancelhe): uma primeira análise artefactual Telma Susana O. Ribeiro

${ }_{1141}$ A cividade de Bagunte. O estado atual da investigação Pedro Brochado de Almeida

1153 Zoomorfos na cerâmica da Idade do Ferro no NW Peninsular: inventário, cronologias e significado Nuno Oliveira / Cristina Seoane

1163 Vasos gregos em Portugal: diferentes maneiras de contar a história do intercâmbio cultural na Idade do Ferro

Daniela Ferreira

1175 Os exotica da necrópole da Idade do Ferro do Olival do Senhor dos Mártires (Alcácer do Sal) no seu contexto regional

Francisco B. Gomes

\section{Antiguidade Clássica e Tardia}

1191 O uso de madeira como combustível no sítio da Quinta de Crestelos (Baixo Sabor): da Idade do Ferro à Romanização Filipe Vaz / João Tereso / Sérgio Simões Pereira / José Sastre / Javier Larrazabal Galarza / Susana Cosme / José António Pereira / Israel Espi

1207 Cultivos de Época Romana no Baixo Sabor: continuidade em tempos de mudança? João Pedro Tereso / Sérgio Simões Pereira / Filipe Santos / Luís Seabra / Filipe Vaz

1221 A casa romana na Hispânia: aplicação dos modelos itálicos nas províncias ibéricas Fernanda Magalhães / Diego Machado / Manuela Martins

1235 As pinturas murais romanas da Rua General Sousa Machado, n. ${ }^{5}$ 1, Chaves José Carvalho

1243 Trás do Castelo (Vale de Mir, Pegarinhos, Alijó) - Uma exploração agrícola romana do Douro

Tony Silvino / Pedro Pereira

1255 A sequência de ocupação no quadrante sudeste de Bracara Augusta: as transformações de uma unidade doméstica Lara Fernandes / Manuela Martins

1263 Os Mosaicos com decoração geométrica e geométrico-vegetalista dos sítios arqueológicos da área do Conuentus Bracaraugustanus. Novas abordagens quanto à conservação, restauro, decoração e datação Maria de Fátima Abraços / Licínia Wrench

1277 “Casa Romana” do Castro de São Domingos (Cristelos, Lousada): Escavação, Estudo e Musealização Paulo André de P. Lemos

1291 A arqueobotânica no Castro de Guifões (Matosinhos, Noroeste de Portugal): O primeiro estudo carpológico

Luís Seabra / Andreia Arezes / Catarina Magalhães / José Varela / João Pedro Tereso 
1305 Um Horreum Augustano na Foz do Douro (Monte do Castelo de Gaia, Vila Nova de Gaia) Rui Ramos

1311 Ponderais romanos na Lusitânia: padrões, formas, materiais e contextos de utilização Diego Barrios Rodríguez

1323 Um almofariz centro-itálico na foz do Mondego

Marco Penajoia

1335 Estruturas romanas de Carnide - Lisboa Luísa Batalha / Mário Monteiro / Guilherme Cardoso

1347 O contexto funerário do sector da "necrópole NO" da Rua das Portas de S. Antão (Lisboa): o espaço, os artefactos, os indivíduos e a sua interconectividade na interpretação do passado Sílvia Loja, José Carlos Quaresma, Nelson Cabaço, Marina Lourenço, Sílvia Casimiro, Rodrigo Banha da Silva, Francisca Alves-Cardoso

${ }_{1361}$ Povoamento em época Romana na Amadora - resultados de um projeto pluridisciplinar Gisela Encarnação / Vanessa Dias

1371 A Arquitectura Residencial em Mirobriga (Santiago do Cacém): contributo a partir de um estudo de caso Filipe Sousa / Catarina Felício

${ }_{1385}$ O fim do ciclo. Saneamento e gestão de resíduos nos edifícios termais de Mirobriga (Santiago do Cacém)

Catarina Felício / Filipe Sousa

1399 Balsa, Topografia e Urbanismo de uma Cidade Portuária Vítor Silva Dias / João Pedro Bernardes / Celso Candeias / Cristina Tété Garcia

1413 No Largo das Mouras Velhas em Faro (2017): novas evidências da necrópole norte de Ossonoba e da sua ocupação medieval Ricardo Costeira da Silva / Paulo Botelho / Fernando Santos / Liliana Nunes

1429 Instrumentos de pesca recuperados numa fábrica de salga em Ossonoba (Faro) Inês Rasteiro / Ricardo Costeira da Silva / Paulo Botelho

1439 A Necrópole Romana do Eirô, Duas Igrejas (Penafiel): intervenção arqueológica de 2016 Laura Sousa / Teresa Soeiro

1457 Ritual, descarte ou afetividade? A presença de Canis lupus familiaris na Necrópole Noroeste de Olisipo (Lisboa)

Beatriz Calapez Santos / Sofia Simões Pereira / Rodrigo Banha da Silva / Sílvia Casimiro / Cleia Detry / Francisca Alves Cardoso

1467 Dinâmicas económicas em Bracara na Antiguidade Tardia Diego Machado / Manuela Martins / Fernanda Magalhães / Natália Botica

1479 Cerâmicas e Vidros da Antiguidade Tardia do Edifício sob a Igreja do Bom Jesus (Vila Nova de Gaia) Joaquim Filipe Ramos

1493 Novos contributos para a topografia histórica de Mértola no período romano e na Antiguidade Tardia Virgílio Lopes

\section{8. Época Medieval}

1511 Cerâmicas islâmicas no Garb setentrional "português": algumas evidências e incógnitas Constança dos Santos / Helena Catarino / Susana Gómez / Maria José Gonçalves / Isabel Inácio / Gonçalo Lopes / Jacinta Bugalhão / Sandra Cavaco / Jaquelina Covaneiro / Isabel Cristina Fernandes / Ana Sofia Gomes 
1525 Contributo para o conhecimento da cosmética islâmica, em Silves, durante a Idade Média Rosa Varela Gomes

1537 Yábura e o seu território - uma análise histórico-arqueológica de Évora entre os séculos VIII-XII José Rui Santos

1547 A encosta sul do Castelo de Palmela - resultados preliminares da escavação arqueológica Luís Filipe Pereira / Michelle Teixeira Santos

1559 A igreja de São Lourenço (Mouraria, Lisboa): um conjunto de silos e de cerâmica medieval islâmica

Andreia Filipa Moreira Rodrigues

1571 O registo material de movimentações populacionais no Médio Tejo, durante os séculos XII-XIII. Dois casos de "sunken featured buildings", nos concelhos de Cartaxo e Torres Novas Marco Liberato / Helena Santos / Nuno Santos

1585 O nordeste transmontano nos alvores da Idade média. Notas para reflexão Ana Maria da Costa Oliveira

1601 Sepulturas escavadas na rocha do Norte de Portugal e do Vale do Douro: primeiros resultados do Projecto SER-NPVD

Mário Jorge Barroca / César Guedes / Andreia Arezes / Ana Maria Oliveira

1619 "Portucalem Castrum Novum" entre o Mediterrâneo e o Atlântico: o estudo dos materiais cerâmicos alto-medievais do arqueossítio da rua de D. Hugo, nํ. 5 (Porto) João Luís Veloso

1627 A Alta Idade Média na fronteira de Lafões: notas preliminares sobre a Arqueologia no Concelho de Vouzela

Manuel Luís Real / Catarina Tente

1641 Um conjunto cerâmico medieval fora de portas: um breve testemunho aveirense Susana Temudo

${ }_{1651}$ Os Lóios do Porto: uma perspetiva integrada no panorama funerário da Baixa Idade Média à Época Moderna em meios urbanos em Portugal

Ana Lema Seabra

1659 O Caminho Português Interior de Santiago como eixo viário na Idade Média Pedro Azevedo

1665 Morfologia Urbana: Um exercício em torno do Castelo de Ourém André Donas-Botto / Jaqueline Pereira

1677 Intervenção arqueológica na Rua Marquês de Pombal/Largo do Espírito Santo (Bucelas, Loures)

Florbela Estêvão / Nathalie Antunes-Ferreira / Dário Ramos Neves / Inês Lisboa

1691 O Cemitério Medieval do Poço do Borratém e a espacialidade funerária na cidade de Lisboa Inês Belém / Vanessa Filipe / Vasco Noronha Vieira / Sónia Ferro / Rodrigo Banha da Silva

1705 Um Espaço Funerário Conventual do séc. XV em Lisboa: o caso do Convento de São Domingos da Cidade Sérgio Pedroso / Sílvia Casimiro / Rodrigo Banha da Silva / Francisca Alves Cardoso

\section{9. Época Moderna e Contemporânea}

1721 Arqueologia Moderna em Portugal: algumas reflexões críticas em torno da quantificação de conjuntos cerâmicos e suas inferências históricas e antropológicas Rodrigo Banha da Silva / André Bargão / Sara da Cruz Ferreira

1733 Faianças de dois contextos entre os finais do século XVI e XVIII do Palácio dos Condes de Penafiel, Lisboa

Martim Lopes / Tomás Mesquita 
1747 Um perfil de consumo do século XVIII na foz do Tejo: O caso do Mercado da Ribeira, Lisboa Sara da Cruz Ferreira / Rodrigo Banha da Silva / André Bargão

1761 Os Cachimbos dos Séculos XVII e XVIII do Palácio Mesquitela e Convento dos Inglesinhos (Lisboa)

Inês Simão / Marina Pinto / João Pimenta / Sara da Cruz Ferreira / André Bargão / Rodrigo Banha da Silva

1775 "Tomar os fumos da erua que chamão em Portugal erua sancta». Estudo de Cachimbos provenientes da Rua do Terreiro do Trigo, Lisboa

Miguel Martins de Sousa / José Pedro Henriques / Vanessa Galiza Filipe

1787 Cachimbos de Barro Caulínitico da Sé da Cidade Velha (República de Cabo Verde)

Rodrigo Banha da Silva / João Pimenta / Clementino Amaro

1801 Algumas considerações sobre espólio não cerâmico recuperado no Largo de Jesus (Lisboa) Carlos Boavida

1815 Adereços de vidro, dos séculos XVI-XVIII, procedentes do antigo Convento de Santana de Lisboa (anéis, braceletes e contas)

Joana Gonçalves / Rosa Varela Gomes / Mário Varela Gomes

1837 Da ostentação, luxo e poder à simplicidade do uso quotidiano: arqueologia e simbologia de joias e adornos da Idade Moderna Portuguesa Jéssica Iglésias

1849 Os amuletos em Portugal - dos objetos às superstições: o coral vermelho Alexandra Vieira

1865 Cerâmicas de Vila Franca de Xira nos séculos XV e XVI Eva Pires

1879 «Não passa por teu o que me pertence». Marcas de individualização associadas a faianças do Convento de Nossa Senhora de Aracoeli, Alcácer do Sal Catarina Parreira / Íris Fragoso / Miguel Martins de Sousa

1891 Cerâmica de Leiria: alguns focos de produção

Jaqueline Pereira / André Donas-Botto

1901 Os Fornos na Rua da Biquinha, em Óbidos Hugo Silva / Filipe Oliveira

1909 A casa de Pêro Fernandes, contador dos contos de D. Manuel I: o sítio arqueológico da Silha do Alferes, Seixal (século XVI) Mariana Nunes Ferreira

1921 O Alto da Vigia (Sintra) e a vigilância e defesa da costa Alexandre Gonçalves / Sandra Santos

1937 O contexto da torre sineira da Igreja de Santa Maria de Loures Paulo Calaveira / Martim Lopes

1949 A Necrópole do Hospital Militar do Castelo de São Jorge e as práticas funerárias na Lisboa de Época Moderna Susana Henriques / Liliana Matias de Carvalho / Ana Amarante / Sofia N. Wasterlain

1963 SAND - Sarilhos Grandes Entre dois Mundos: o adro da Igreja e a Paleobiologia dos ossos humanos recuperados

Paula Alves Pereira / Roger Lee Jesus / Bruno M. Magalhães

1975 Expansão urbana da vila de Cascais no século XVII e XVIII: a intervenção arqueológica na Rua da Vitória no 15 a 17

Tiago Pereira / Vanessa Filipe

1987 Novos dados para o conhecimento do Urbanismo de Faro em época Moderna Ana Rosa 
1995 Um exemplo de Arqueologia Urbana em Alcoutim: o Antigo Edifício dos CTT Marco Fernandes / Marta Dias / Alexandra Gradim / Virgílio Lopes / Susana Gómez Martínez

2007 Palácio dos Ferrazes (Rua das Flores/Rua da Vitória, Porto): a cocheira de Domingos Oliveira Maia

Francisco Raimundo

2021 As muitas vidas de um edifício urbano: História, Arqueologia e Antropologia no antigo Recreatório Paroquial de Penafiel Helena Bernardo / Jorge Sampaio / Marta Borges

2035 O convento de Nossa Senhora da Esperança de Ponta Delgada: o contributo da arqueologia para o conhecimento de um monumento identitário João Gonçalves Araújo / N’Zinga Oliveira

2047 Arqueologia na ilha do Corvo... em busca da capela de Nossa Senhora do Rosário Tânia Manuel Casimiro / José Luís Neto / Luís Borges / Pedro Parreira

2059 Perdidos à vista da Costa. Trabalhos arqueológicos subaquáticos na Barra do Tejo Jorge Freire / José Bettencourt / Augusto Salgado

2071 Arqueologia marítima em Cabo Verde: enquadramento e primeiros resultados do projecto CONCHA

José Bettencourt / Adilson Dias / Carlos Lima / Christelle Chouzenoux / Cristóvão Fonseca / Dúnia Pereira / Gonçalo Lopes / Inês Coelho / Jaylson Monteiro / José Lima / Maria Eugénia Alves / Patrícia Carvalho / Tiago Silva

2085 Trabalhos arqueológicos na Cidade Velha (Ribeira Grande de Santiago, Cabo Verde): reflexões sobre um projecto de investigação e divulgação patrimonial André Teixeira / Jaylson Monteiro / Mariana Mateus / Nireide Tavares / Cristovão Fonseca / Gonçalo C. Lopes / Joana Bento Torres / Dúnia Pereira / André Bargão / Aurélie Mayer / Bruno Zélie / Carlos Lima / Christelle Chouzenoux / Inês Henriques / Inês Pinto Coelho / José Lima / Patrícia Carvalho / Tiago Silva

2103 A antiga fortificação de Quelba / Khor Kalba (E.A.U.). Resultados de quatro campanhas de escavações, problemáticas e perspectivas futuras Rui Carita / Rosa Varela Gomes / Mário Varela Gomes / Kamyar Kamyad

2123 Colónias para homens novos: arqueologia da colonização agrária fascista no noroeste ibérico Xurxo Ayán Vila / José Mạ . Señorán Martín 


\title{
PALÁCIO DOS FERRAZES (RUA DAS FLORES/RUA DA VITÓRIA, PORTO): A COCHEIRA DE DOMINGOS OLIVEIRA MAIA
}

\section{Francisco Raimundo ${ }^{1}$}

\begin{abstract}
RESUMO
No âmbito da empreitada de reabilitação e reconversão do Palácio dos Ferrazes numa unidade hoteleira, cuja implantação englobava dois edifícios, um voltado para a Rua das Flores (Palácio) e outro para a Rua da Vitória (duas unidades fabris) incluindo o logradouro existente entre eles, apresenta-se uma breve caracterização da ocupação do espaço na área correspondente ao segundo edifício. Esta caracterização é elaborada com base no acompanhamento arqueológico do desmonte/demolição do edificado existente, aliada aos dados recolhidos na escavação arqueológica e suplementada por algumas fontes documentais, o que nos permitiu reconstituir a cocheira datada do século XIX, mandada construir por Domingos Oliveira Maia, assim como ocupações anteriores datáveis dos séculos XVII/XVIII.
\end{abstract}

Palavras-chave: Domingos Oliveira Maia, Palácio do Ferrazes, Rua da Vitória, Século XVII/XVIII, Século XIX.

\begin{abstract}
Within the scope of the rehabilitation of the Ferrazes Palace into a hotel unit, whose implementation encompassed two buildings, one facing Rua das Flores (Palácio) and the other facing Rua da Vitória, as well as the existing space between them, we present a short description about the occupation of the second building. This characterization is elaborated based on the archaeological monitoring of the dismantling / demolition of the existing building, combined with the data collected during the archaeological excavation and complemented with some documentary sources that made it possible to reconstruct the old stable dated from the XIX century, ordered to be built by Domingos Oliveira Maia, as well as previous occupations dating from the $17^{\text {th }} / 18^{\text {th }}$ centuries.

Keywords: Domingos Oliveira Maia, Ferrazes Palace, Rua da Vitória, $17^{\text {th }}, 18^{\text {th }}$ and $19^{\text {th }}$ centuries.
\end{abstract}

\section{INTRODUÇÃO}

O conjunto arquitectónico do Palácio dos Ferrazes, comummente conhecido por Casa dos Ferrazes Bravo ou Casa dos Maias, encontra-se numa zona de elevada sensibilidade histórica e arqueológica, estando abrangida pelas servidões administrativas do Centro Histórico do Porto, Ponte Luiz I e Mosteiro da Serra do Pilar (inscrito na Lista do Património Mundial da UNESCO em 1996), da Zona Histórica do Porto e classificado como Imóvel de Interesse Público - Casa dos Ferrazes Bravos (IIP, Decreto n. $\frac{0}{45} / 93$, DR/28o de 30-11-1993).
A área de implantação da empreitada englobava dois edifícios, um voltado para a Rua das Flores e outro para a Rua da Vitória, assim como a zona de logradouro existente entre eles composta por dois socalcos. Os dados históricos disponíveis (Afonso, 2008) situam a primeira construção no local aproximadamente nos inícios do século XVI, cuja evolução dará mais tarde origem à casa de uma das famílias mais notáveis do Porto de seiscentos, os Ferraz Bravo. O segundo edifício, situado na Rua da Vitória, albergava em tempos recentes (segunda metade do século $\mathrm{XX}$ ) duas unidades fabris de pequena dimensão construídas sobre os alicerces de uma co-

1. OMNIKNOS, LDA; franciscoraimundo@omniknos.pt. 
cheira mandada erguer por Domingos de Oliveira Maia em meados do século XIX.

A empreitada em questão, previa a reabilitação do palacete, a construção de um novo edifício de 8 pisos voltado para a Rua da Vitória, a requalificação do logradouro e o restauro da capela oitocentista. Desta forma, a afectação da obra no edifício voltado para a Rua da Vitória foi total, implicando a demolição do edificado existente e o desaterro mecânico do lote até à cota da Rua das Flores. Também os socalcos intermédios foram alvo de afectação total pelas acções de demolição e desaterro mecânico. O edificado correspondente ao Palácio do Ferrazes foi totalmente reabilitado e remodelado, tendo sido demolidas a maioria das suas paredes interiores, substituídas as coberturas e os elementos estruturais em madeira, rebaixada a cota de soleira do edifício e acrescentado um piso ao corpo da ala poente. Este último, foi ampliado de forma a garantir a ligação ao novo edificado.

A abordagem arqueológica realizada teve por base o estudo histórico e espacial elaborado por José Ferrão Afonso, em 2008, sob o título "A casa Ferraz-Bravo na Rua das Flores do Porto", bem como o relatório preliminar dos trabalhos Arqueológicos aí desenvolvidos no ano de 2008, pela empresa Era-Arqueologia, S.A. Os trabalhos de acompanhamento arqueológico deram cumprimento às medidas de minimização propostas neste último, assim como ao parecer prévio emitido pela DRCN, em Novembro 2016, e tiveram a duração de 24 meses $^{2}$. Todos os trabalhos de demolição, desmonte de estruturas, levantamento de pisos e movimentação de terras foram alvo de acompanhamento arqueológico, tendo-se elaborado o registo fotográfico da evolução da empreitada, procedendo-se ao registo fotográfico e gráfico (à escala 1/20) dos elementos patrimoniais e de todos os vestígios/pormenores considerados úteis para a compreensão de evolução do edificado. De salientar que durante o acompanhamento da demolição do edifício da Rua da Vitória, foram identificadas várias estruturas relacionadas com anteriores

\footnotetext{
2. No decurso dos trabalhos integraram a equipa técnica de campo os arqueólogos Ana Cristina Hermínio, Carlos Jorge, Cristiana Valpaços, Fátima Costa, Marco Araújo Pereira, João Hipólito, José Nuno Gomes, Óscar Teixeira, Tiago Gil e Vítor Gomes, dirigidos pelo arqueólogo responsável Francisco Raimundo, sendo a coordenação dos trabalhos arqueológicos e gestão de projeto realizada pelo departamento técnico da ERA-Arqueologia.
}

ocupações do espaço, o que conduziu à adopção de medidas de minimização que implicaram a escavação arqueológica, em área, de todo o patamar ao nível da Rua da Vitória.

\section{ENQUADRAMENTO GEOGRÁFICO E HISTÓRICO}

Os imóveis onde se localizaram os trabalhos de acompanhamento arqueológico situam-se entre a Rua das Flores (números 21 a 39) e a Rua da Vitória (149 a 157), ambos pertencentes às antigas freguesias da Sé e da Vitória, que desde 2012, por força da reorganização administrativa do território, introduzida pela Lei n.ำ 22/2012 de 30 de maio, integram a União das Freguesias de Cedofeita, Santo Ildefonso, Sé, Miragaia, São Nicolau e Vitória, criada por agregação das extintas freguesias de Cedofeita, Miragaia, Santo Ildefonso, São Nicolau e das anteriormente citadas.

A Rua das Flores terá sido mandada rasgar no ano de 1521 por ordem do rei D. Manuel I, visando estabelecer ligação entre o mosteiro feminino de S. Bento da Ave-Maria, construído, em 1518, e o Largo onde se situava o convento de S. Domingos. O traçado da Rua das Flores é coincidente com o da antiga estrada de Guimarães, que estará na origem dos antigos caminhos das Barreiras, do rio da Vila e das ruas de serviço das habitações que aí se viriam a construir (Afonso, 2008, p.5). O carácter inovador desta rua, deve-se sobretudo, à regularidade do loteamento, especialmente na zona próxima ao Largo de São Domingos, com frentes de seis varas (6,6o metros), e à considerável extensão dos lotes, onde existiriam grandes e flóreos jardins, que terão estado na origem do nome do novo arruamento, a Rua de Santa Catarina das Flores (Afonso, 2001).

A zona onde se erigiram as construções, que mais tarde vieram a enformar o 'Palácio dos Ferrazes' integrava terrenos propriedade da Mitra da Sé do Porto, então conhecidos como as "Hortas do Bispo". Estes confrontavam com os do Cabido e com os terrenos da recém-fundada Santa Casa da Misericórdia do Porto. Logo após a sua construção, a Rua das Flores adquire uma importância vital como eixo estruturante da dinâmica social e comercial da cidade intramuros e, é nela, que se instalam as residências das principais famílias aristocráticas e burguesas e as mais ricas lojas da cidade (Barbosa, 2015, 160).

Os Ferraz Bravo serão dos primeiros proprietários da rua. Em 1542, o Tombo das propriedades da Mi- 
tra refere Manuel Bravo como proprietário de três chãos, sendo que, em dois destes chãos, já se achavam erguidas casas e no terceiro apenas os portais. Uma das casas terá pertencido a Manuel Carneiro e Ana Bravo (filha de Catarina Bravo, por sua vez sobrinha de Manuel Bravo) e outra a Martim Ferraz por casamento com Catarina Rebelo (filha de Manuel Bravo e Maria Carneiro), uniões que terão consolidado os laços entre as duas famílias, Bravo e Ferraz. Entre 1639 e 1697 a propriedade agregava já os quatro chãos, sendo dela proprietários Miguel Ferraz Bravo e seus irmãos (Afonso, 2008, p.6-7).

Em 1746, ano em que se procedeu ao reconhecimento das propriedades da Mitra, da qual os quatro chãos eram foreiros, a habitação aparecia designada como 'morada de casas nobres'. Esta vedoria apresenta uma detalhada descrição do espaço construído. Segundo este documento, na fachada abrir-se-iam apenas dois portões, quatro janelas de peitoril e duas portas pequenas, estas no corpo poente. A existência de janelas de peitoril poderá estar relacionada com uma ocupação comercial dos chãos do edifício, já que o aluguer das lojas para comércio era prática comum, também nas casas nobres (Afonso, 2008, p. 8).

O século que se seguiu à vedoria é o período menos conhecido e sobre o qual dispomos de parca ou nenhuma informação acerca dos proprietários do edifício. O Tombo da Mitra refere que a propriedade foi legada à casa professa de São Roque da Companhia de Jesus, que era a administradora do legado perpétuo de Bartolomeu Ferraz de Almeida, talvez o último elemento da família em posse do edifício (Afonso, 2008, p.12). Assim, nas primeiras décadas do século XVIII este não estaria já na posse da família fundadora. Sabemos, todavia, que as principais alterações ao edificado, sobretudo ao nível da fachada, terão ocorrido durante a segunda metade da centúria de setecentos.

Nos alvores do século XIX o proprietário do palácio era António de Oliveira Maia, como atesta o pedido de licenciamento de alterações na fachada aprovado a 27 de Maio de 1810 (Afonso, 2008, p.13). Estas modificações contemplaram a transformação de duas janelas de peitoril em dois portões centrais, conferindo a monumentalidade e simetria que ainda se podem apreciar na fachada actual. A aquisição do edifício terá sido por compra, embora não disponhamos de nenhum documento que o confirme (Figura 1).

Com a morte de António Maia, sucedeu-lhe na casa o seu filho Domingos de Oliveira Maia, que será porventura o proprietário mais conhecido da 'Casa dos Ferrazes Bravo', ou 'Casa dos Maias', como terá passado a ser designada no século XIX. Este promoveu alterações importantes no Palácio e no jardim do mesmo, saindo da sua pena o projecto de construção da cocheira voltada à Rua da Vitória datado de 1851 . Grande capitalista da cidade do Porto de oitocentos, Fidalgo-Cavaleiro da Casa Real - foi também Diretor do Banco Comercial do Porto, Jurado da Inspeção-geral dos Teatros e Espetáculos Públicos Nacionais, Irmão da Real Irmandade da Ordem de Nossa Senhora da Lapa e Membro da Comissão da Câmara Municipal do Porto para levantar o monumento a Dom Pedro V - é reconhecido pelos seus projectos e realizações arquitectónicas, das quais se destaca a Casa do Passeio Alegre (Graça, 2004, p.213, apud Afonso, 2008, p.13). Domingos de Oliveira Maia, quer pelos vínculos familiares, quer pelos cargos que exerceu, assumiu uma posição privilegiada na sociedade portuense da primeira metade do século XIX. Muito mais do que aristocrata ou negociante - ou 'comerciante', como jocosamente o tratavam alguns - Oliveira Maia era um ilustrado viajante (Resende, 2017, p.345) que conhecia as principais cidades da Europa (Graça, 2007, p.323-325; Encarnação, 2012-2013, p.126) e dispunha de uma vasta e diversa rede de contactos dentro e fora do país. Estas particularidades ajudarão a compreender, em parte, as transformações levadas a cabo no edificado do palácio.

Após a morte deste, a casa foi herdada pela sua irmã Maria Ludovina de Oliveira Maia. A partir daí sabemos muito pouco sobre o destino do Palácio, apenas que terá ficado na posse dos herdeiros desta até finais do século XX. Nesse século, o edifício foi ocupado por algumas lojas das quais se destacam o alfarrabista Chaminé da Mota e a Barbearia Brasão (Afonso, 2008, p.19). Também o edifício voltado para a Rua da Vitória sofreu alterações importantes durante este período, tendo sido dividido em duas unidades autónomas, onde terão laborado duas indústrias, encontrando-se, muito provavelmente, já desanexado do lote correspondente ao palácio.

Nos últimos anos do século $\mathrm{XX}$, tanto o palácio como o edificado voltado para a Rua da Vitória entraram num processo acelerado de degradação que apenas viria a ser revertido com o início da empreitada de reabilitação no ano de 2016, com vista à construção do "Hotel Palácio dos Ferrazes”, inaugurado em Setembro de 2019 sob o nome de "Hotel Portobay Flores". 


\section{TRABALHOS ARQUEOLÓGICOS}

Os trabalhos arqueológicos decorreram entre os meses de Novembro de 2016 e 2018 na totalidade da área a ser intervencionada pela empreitada de reconstrução e ampliação do Palácio dos Ferrazes, com especial enfoque no edifício correspondente ao Palácio e no edificado voltado para a Rua da Vitória. Todas as acções que implicaram demolições, desaterros, abertura de valas e escavação (manual e mecânica), no subsolo e no edificado do palácio, pátio exterior, socalcos e unidades fabris, e que permitiram aportar novas informações acerca da evolução do edificado, foram objecto de registo fotográfico e, sempre que possível, de registo gráfico e descritivo, o que originou um portefólio de 171 desenhos de campo, na sua grande maioria à escala 1/20.

No decorrer dos trabalhos de acompanhamento arqueológico na área correspondente ao edificado voltado para a Rua da Vitória, e quando se acompanhava a remoção dos pisos térreos, foram identificadas várias estruturas que aparentavam não corresponder ao edificado datado do século XX. A possibilidade destas estruturas poderem estar relacionadas com a cocheira projetada por Domingos de Oliveira Maia no século XIX ou com alguma construção de cronologia anterior, conduziu à suspensão dos trabalhos e à comunicação com as entidades tutelares, sendo que as medidas de minimização a implementar, à semelhança do que fora proposto no relatório das sondagens de diagnóstico realizadas em 2008, passariam pela escavação de toda a área por forma a registar e caracterizar os vestígios identificados.

\subsection{Acompanhamento Arqueológico}

Durante o acompanhamento arqueológico dos trabalhos de desmonte/demolição dos edifícios com os números 149 a 157, sitos na Rua da Vitória, onde terão laborado duas indústrias durante a segunda metade do século XX, foram identificados alguns pormenores construtivos que estarão relacionados com a cocheira do século XIX e que terão servido de base à construção das duas unidades fabris (Figura 2). Nas paredes laterais que fazem divisão de propriedade com os lotes contíguos, é perceptível o aumento feito às paredes da cocheira de modo a subir a cota da fachada voltada para a Rua da Vitória que terá ocorrido em meados do século XX.

A parede do edifício situado a nascente apresenta ainda o negativo do edificado que terá pertencido à cocheira, o que indica que quando esta parede foi rebocada o edifício localizado neste lote apresentava ainda as suas características originais. Também na parede poente, que faz divisão com a Santa Casa da Misericórdia, é visível o acrescento feito no canto superior esquerdo, bem como, na outra extremidade, os três encaixes que serviriam de suporte ao segundo piso da cocheira.

Na fachada tardoz, no edificado da unidade fabril encostada ao lote da Santa Casa da Misericórdia, foram ainda identificadas quatro janelas, duas no piso ao nível da Rua da Vitória e as restantes no piso superior, construídas com moldura em granito. As duas janelas do piso inferior terão sido transformadas em portas durante a ocupação do espaço pela fábrica.

A remoção dos entulhos permitiu colocar a descoberto parte de um lajeado de grandes dimensões formado por lajes de granito. Na área nascente deste lajeado foram registados uma série de sulcos que formavam um reticulado, provavelmente associados à cocheira do século XIX. O facto de este lajeado se encontrar coberto por uma espessa camada de cimento, que remontará à ocupação do espaço durante o século XX, não permitiu o seu registo integral. De qualquer das formas, foi possível comprovar que este cobria toda a área do patamar ao nível da Rua da Vitória (Figura 3).

Abaixo do piso do edifício da fábrica, localizado ao nível da Rua da Vitória, foram registados vários elementos que pertenceriam à cocheira do século XIX e que foram aproveitadas na instalação da unidade fabril. Foi identificada uma escadaria interior de acesso à cocheira passando no topo desta para o exterior através de um vão aberto na parede traseira da cocheira. Daqui, seguiam duas andainas de escadas, uma para cada lado, que eram formadas por lajes de granito inseridas na parede e que derivavam nas extremidades para dentro do edifício. Na parede traseira, para além da porta de lintel arredondado, foi também registada uma janela de lintel semi-circular, localizada sensivelmente a meio da escadaria, e acima desta um peitoril de uma outra janela que não chegou a ser terminada.

Ainda embutida na parede traseira, e também relacionada com a cocheira do século XIX, foi registada uma fonte de morfologia semelhante à existente no terceiro socalco do logradouro. Esta estrutura, de planta rectangular e abóbada em arco abatido construída em tijolo de burro e rematada na face exterior por uma moldura em silhares graníticos, inte- 
grava um tanque formado por quatro grandes blocos graníticos. O abastecimento desta fonte era feito por uma mina, composta por um corredor em forma de 'L' por onde corriam várias canalizações que conduziam a água para o tanque da fonte (Figura 4). Com base nos resultados obtidos com o acompanhamento arqueológico do desmonte do edificado existente foi possível proceder à reconstituição parcial do alçado tardoz da cocheira do século XIX, à excepção da zona central por onde era feito o acesso ao interior do edifício através das duas andainas de escadas, bem como do acesso entre o Palácio e a cocheira através do logradouro (Figura 5).

\subsection{Escavação Arqueológica}

No decorrer dos trabalhos de acompanhamento arqueológico e coincidindo com a entrada da maquinaria pesada em obra, a fim de iniciar a escavação mecânica da área correspondente ao edificado voltado para a Rua da Vitória (números 149 a 157), foram identificadas várias estruturas que aparentavam não corresponder ao edificado datado do século XX. O facto destas estruturas poderem estar relacionadas com a cocheira projectada por Domingos de Oliveira Maia, em 1851, ou até mesmo com um edifício anterior a esta, conduziu à suspensão dos trabalhos e à comunicação com as entidades tutelares. Em reunião, realizada no local, ficou determinado que as medidas de minimização a implementar, à semelhança do que fora proposto no relatório das sondagens de diagnóstico realizadas em 2008, passariam pela escavação em área de modo a colocar todas as estruturas a descoberto, permitindo assim, o seu correcto registo e caracterização.

Constrangimentos relacionados com o decorrer da empreitada e a necessidade de manter parte do patamar a intervencionar para apoio aos trabalhos de desaterro a desenvolver nos patamares inferiores designadamente para a montagem de uma autogrua - não permitiram a escavação simultânea de toda a área, pelo que os trabalhos de escavação arqueológica foram divididos em quatro fases (Figura 6).

A primeira fase (Janeiro 2017) incidiu sobre a parte central mais recuada do patamar, onde foram identificados os muros correspondentes ao alicerce da cocheira da segunda metade do século XIX, que se encontravam preenchidos por vários depósitos associados a uma regularização da cota do socalco para a construção da cocheira. Foi também colocada a descoberto parte da parede tardoz da cocheira cons- truída em alvenaria de pedra de grandes dimensões e argamassa, que se encontrava suportada por dois contrafortes interiores em alvenaria preenchida com pedra miúda e argamassa. Adossados a estes, existiam dois muros de construção semelhante, mas de menor profundidade, que parecem corresponder a alicerces para suporte das paredes representadas na planta de 1851 . Sob estas estruturas situava-se uma fonte e respectiva mina de água que será coetânea da construção da cocheira. A mina, composta por um corredor em forma de 'L' por onde corriam duas canalizações: a primeira, construída em telha de meia cana sobre um pequeno murete argamassado, abastecia de água uma pia/depósito rectangular de granito coberto por 3 lajes de xisto e que depois seguia através de um canalização de chumbo até à cozinha situada no segundo piso da ala poente do palácio; a segunda, situada ao nível do chão, era composta por uma fiada de telha de meia cana adossada a uma tubagem cerâmica, que conduzia a água para o tanque da fonte. A fonte, de planta rectangular e abóbada em arco abatido construída em tijolo de burro e rematada na face exterior por uma moldura em silhares graníticos, integrava um tanque formado por quatro grandes blocos graníticos.

Aparentemente todos os muros identificados pertenceriam à cocheira do século XIX, à excepção de uma estrutura de planta rectangular, que parece tratar-se de um tanque, e que estará relacionado com a indústria que aí laborou durante o século XX. A construção desta estrutura implicou o corte de um dos muros que compõem as fundações da cocheira. A segunda fase (Junho 2017) consistiu na abertura de duas sondagens de planta rectangular, com cerca de 5,6o metros de comprimento por 2,10 metros de largura e 1 metro de profundidade ( $\mathrm{S}_{1}$ e S2), na zona central do lote - decorrente da necessidade de construir duas sapatas de apoio à auto-grua, imprescindível para içar a maquinaria da obra. A escavação desta área colocou a descoberto a continuação dos muros identificados na primeira fase, parte do muro correspondente à fachada da cocheira do século XIX e duas caixas de saneamento com as respectivas tubagens. Uma das caixas construída em betão estaria associada a uma casa de banho existente no edifício fabril poente (SI), a segunda construída em alvenaria de pedra de granito de feição sub-circular estaria relacionada com o aqueduto também em pedra, ambos coetâneos da construção da cocheira no século XIX (S2). Posteriormente, aquando da construção do 
edificado fabril foi colmatada com cimento e ligada a uma conduta de grés que rasgou parte do muro da fachada da cocheira e do aqueduto em pedra.

A terceira fase (Outubro 2017) incidiu sobre toda a parte nascente do patamar e aquela por escavar entre as duas sondagens acima descritas e revelou a continuação das estruturas correspondentes ao edificado da cocheira: a fachada e respectivo alicerce, os dois contrafortes interiores e os alicerces a estes adossados, já descritos na primeira fase.

Abaixo destas identificou-se uma construção de planta aparentemente rectangular, em alvenaria de pedra miúda e argamassa, rebocada e pintada de cinzento na face exterior voltada ao Palácio. Esta estrutura corresponderá a um edifício mais antigo e terá sido cortada pela construção da mina de água que abastecia a fonte embutida na parede tardoz da cocheira. No topo desta estrutura eram ainda visíveis os negativos correspondentes a entalhes onde assentariam estruturas perecíveis (tabique?). No canto Sul foi registado parte de um empedrado composto por blocos irregulares de pequena e média dimensão, preenchido por um sedimento argiloso e com marcas de desgaste pelo uso e uma soleira com sulcos quadrangulares nas extremidades.

Este muro antigo desenvolvia-se desde a parede que faz divisão com o terreno da Santa Casa da Misericórdia até cerca de um metro da parede do edifício do Instituto Português de Fotografia (IPF) onde flectia para Noroeste. Assim, neste pequeno espaço entre os dois edifícios terá existido uma pequena passagem entre a Rua da Vitória e um socalco localizado nas traseiras do edifício.

Os materiais aí exumados apontam para uma cronologia entre finais do século XVII e inícios do século XVIII.

A quarta fase (Dezembro 2017) incidiu na parte poente da plataforma, junto à parede meeira com a Santa Casa da Misericórdia, e permitiu confirmar a continuação das estruturas relacionadas com as duas ocupações já conhecidas, que se estendiam até ao limite do lote. Sob estes vestígios, registou-se ainda parte de um muro em alvenaria de pedra seca que pertenceria a uma construção anterior, cuja cronologia não foi possível aferir dada a ausência de espólio associado (Figura 7).

\section{SÍNTESE INTERPRETATIVA}

Os trabalhos de escavação arqueológica realizados na área onde se situava o edifício voltado para a Rua da Vitória, permitiram colocar a descoberto uma série de estruturas relacionadas com a Cocheira projectada por Domingos de Oliveira Maia, em meados do século XIX, e com os edifícios que se lhe sobrepuseram no século $X X$, relacionados com duas indústrias que aí laboraram. Abaixo destas, foram detectadas estruturas que aparentam reportar a cronologias anteriores, das quais não se conhecia referência e que, com base nos materiais exumados, podem remontar aos séculos XVII/XVIII.

Segundo a vedoria de 1746, a casa nobre a que mais tarde se chamou Palácio dos Ferraz/Bravo possuía um "quintal [com] muitas arvores de fruto, e laranjeyras, e esta feito em quatro taboleyros, e nos tres primeiros da parte do sul tem em cada hum sua fonte de agoa com seo tanque de pedra, cuja agoa vem do tanque do chatariz da Porta do Olival e tem para a parte do norte sua porta e serventia" (Arquivo Distrital do Porto, Cabido, 5399, fls $214 \mathrm{v}^{\mathrm{o}}-216 \mathrm{v}^{\mathrm{o}}$ Apud Afonso, 2001, pp. 265-266). Todavia, os trabalhos de escavação arqueológica colocaram a descoberto vestígios de edifícios que poderão ser anteriores a esta cronologia, embora a ausência de material arqueológico associado não permita confirmar esta suposição. Acima desta estrutura, foi exumada a parede tardoz e lateral de um edifício posterior, que de acordo com os materiais que lhe estão associados, terá sido construído em finais do século XVII ou inícios do século XVIII. Este edifício apresenta uma planta rectangular, com plataforma construída em alvenaria de pedra miúda e de média dimensão argamassada, rebocada no exterior e pintada de cinzento. As paredes acima do piso de circulação seriam constituídas por materiais perecíveis (tabique?), facto sugerido pelos inúmeros entalhes identificados nos silhares de topo das sapatas. Esta construção não encostaria ao edifício localizado a norte (actual IPF) dado que foram encontrados vestígios da existência de um acesso à rua da Vitória, provavelmente através de uma escadaria composta por silhares de granito, da qual foi possível identificar um degrau durante os trabalhos de acompanhamento. Tal parece ser confirmado pela planta do arquitectos Joaquim da Costa Lima Júnior, datada de 23 de Janeiro de 1851, onde se propõe um "novo alinho que a Exma. Câmara Muni- 
cipal projeta dar à Viela dos Calhaus" e se encontra já representada a planta da cocheira projectada por Domingos da Maia. Nessa mesma planta, é representado um vão de acesso à rua da Vitória que terá sido encerrado com a construção da dita cocheira e que corresponderá aquele identificado no decorrer dos trabalhos arqueológicos (Figura 8).

Esse edifício prolongar-se-ia para noroeste (actual Rua da Vitória), mas terá sido cortado pela construção da fachada da cocheira que parece respeitar o novo alinhamento ditado pela Câmara Municipal. As estruturas identificadas no decurso da escavação arqueológica, nomeadamente aquelas voltadas à actual Rua da Vitória, e que podem ser atribuídas à cocheira parecem decalcar a planta constante no projecto de Domingos Oliveira Maia, aprovada em 1851 (Figura 9).

A cocheira terá sido construída aproveitando as paredes de um edifício já existente, sobre o qual se ergueram dois contrafortes que serviram de suporte a uma parede traseira levantada de raiz e na qual se construiu uma fonte com tanque de água e mina de acesso. As paredes eram robustas e construídas em alvenaria de pedra de média e grande dimensão com argamassa de saibro e cal. Por forma a aumentar o tamanho do patamar voltado à rua da Vitória, procedeu-se ao aterro do socalco superior, o que possibilitou aumentar a área de construção. Conforme projectado na planta de 1851, a cocheira era composta por dois pisos, o primeiro recuado em relação à rua e um piso térreo com um lajeado granítico de grandes dimensões, que apresentava uma trama quadriculada de caneluras das quais desconhecemos a função. Desconhece-se quando é que a cocheira terá deixado de o ser, mas sabe-se que pelo menos até à década de 40 do século $\mathrm{XX}$, o edifício terá mantido a sua traça original, como se comprova pelas fotografias aéreas dos anos 30-40, nas quais se observa uma panorâmica de todo o lote correspondente ao Palácio dos Ferrazes e se assinala a ausência do corpo tardoz poente, que terá sido acrescentado a esta construção em fase posterior (Figura 10).

Na segunda metade do século XX, o edifício onde existia a cocheira terá sido dividido em duas partes iguais, sendo que à metade poente foi acrescentado um outro edifício, e a metade nascente terá sofrido grandes alterações ao nível das paredes estruturais. Aí, segundo o estudo histórico e espacial de J. Afonso, terão funcionado duas unidades indus- triais, das quais não foi possível até à data apurar a que se dedicavam.

\section{CONSIDERAÇÕES FINAIS}

Os contextos identificados no decorrer dos trabalhos arqueológicos correspondem a um quadro cronológico compreendido entre o século XVI e o XX e fornecem dados importantes no que respeita à evolução do espaço construído e às sucessivas transformações de que foi alvo.

Foram identificados e recolhidos uma série de materiais arqueológicos que ajudam a compreender a vivência quotidiana no espaço ao longo dos últimos séculos. Destacam-se também, os elementos arquitectónicos de características particulares ou únicas, como é o caso da fonte renascentista existente no piso térreo do palácio, ou a lareira e chaminé da cozinha do primeiro piso do Palácio, cuja preservação foi possível conciliar com as alterações previstas no projecto de arquitectura.

Se os trabalhos arqueológicos permitiram reunir um corpus de informações relevantes para a caracterização da ocupação humana do espaço entre os séculos XVII e XIX, os mesmos, revelaram-se inconclusivos em relação às ocupações mais recentes do palácio e do edifício voltado para a Rua da Vitória, nomeadamente no que alude às indústrias que aí terão laborado e que são por nós desconhecidas. Tal informação só poderá ser recuperada através de um estudo aprofundado das fontes documentais disponíveis relativas ao último século.

Conquanto, através do acompanhamento arqueológico dos trabalhos de desmonte/demolição do edificado existente junto à Rua da Vitória, em conjunto com os dados recolhidos através da escavação arqueológica manual de toda esta área e complementado pelas fontes documentais, foi possível executar uma boa caracterização da cocheira datada de meados do século XIX, mandada construir por Domingos de Oliveira Maia.

Tendo em conta a complexidade da intervenção e o vasto conjunto de informação reunida, as considerações que por ora se apresentam são ainda incipientes, carecendo de aturado exame e confrontação com um leque mais alargado das fontes documentais disponíveis. 


\section{BIBLIOGRAFIA}

AFONSO, J. F. (2001) - A rua das Flores no século XVI. Elementos para a história urbana do Porto quinhentista. Porto: F.A.U.P.

AFONSO, J. F. (2008) - A casa Ferraz - Bravo na rua das Flores do Porto, Estudo histórico e espacial.

BARBOSA, J. F. (2017) - "Reabilitação do património, cidade do Porto: estratégias e factos - Rua (Sta. Catarina) das Flores". Revista Arquitetura Lusíada, 7 (1.․osemestre 2015): 153-206.

BARREIRA, Paula; GOMES, Paulo Dórdio; TEIXEIRA, Ricardo (1995) - “200 anos de cerâmica na Casa do Infante: do século XVI a meados do século XVIII". In Actas das 2.as Jornadas de Cerâmica Medieval e Pós-Medieval, métodos e resultados para o seu estudo. Tondela: Câmara Municipal, pp. $145^{-184}$.

CASIMIRO, T.M. (2013) - "Faiança Portuguesa: datação e evolução crono-estilística”. Revista Portuguesa de Arqueologia, 14: 355-373.

ENCARNAÇÃO, J. (2012-2013) - “Uma pátera envolta em mistério?", Anas, 25-26:117-132.

FLÓRIDO, M. (2010) - “Tipificação de Soluções de Reabilitação de Paredes de Madeira em Edifícios Antigos”, FEUP, Dissertação submetida para satisfação parcial dos requisitos do grau de Mestre em Engenharia Civil - Especialização em Construções Civis, pp. 12-20.

GOMES, Paulo Dórdio; TEIXEIRA, Ricardo Jorge; SÁ, Anabela (2001) - "Faianças do Porto e Gaia: o recente contributo da arqueologia". In Itinerário da Faiança do Porto e Gaia. Porto: Museu Nacional de Soares dos Reis, pp. 117-166.

GRAÇA, M. S. A. (2007) - "Domingos de Oliveira Maya percurso de um riscador amador ou da responsabilidade técnica no Porto de meados de Oitocentos", In Natália Marinho Ferreira-Alves (Coord.) Artistas e Artífices e sua Mobilidade no Mundo de Expressão Portuguesa, ACTAS VII Colóquio Luso-Brasileiro de História da Arte, DCTP-FLUP, pp. 321-330.

OSÓRIO, M. (2014) - "Sobre as marcas cruciformes do Concelho do Sabugal”. In SARAIVA, António e CAMEIJO, Alcina (Org.) Judeus, Judiarias e Cristãos-Novos na Beira Interior. Guarda: Agência para a Promoção da Guarda, pp. 157-166. [versão digital disponível em https://www. academia.edu/10168733/Sobre_as_marcas_cruci-formes_ do_Concelho_do_Sabugal]

REBUGE, J. e PINTO, M. (2008) - Relatório Preliminar dos trabalhos Arqueológicos, Sondagem de Diagnóstico Arqueológico na Rua das Flores, n.. 25-33 ("Casa Ferraz-Bravo, Casa dos Maias”); Rua da Vitória, n.․149-157, Era-Arqueologia, SA.

RESENDE, N. (2017) - “"Para aprender, viajar e escrever»: uma carta para Domingos de Oliveira Maia (1821)”, CEM Cultura, Espaço \& Memória, 8: 339-356.
SOUSA, F. \& CIRNE, T. (2007) - "Portugueses do norte de Portugal com destino ao Brasil (1805-1832)", In Fernando de Sousa et all (Coord.) A Imigração Portuguesa para o Brasil, CEPESE - Centro de Estudos da População, Economia e Sociedade / Edições Afrontamento, pp. 489-556.

\section{FONTES CARTOGRÁFICAS E OUTRAS}

Cidade do Porto / T. S. Maldonado delin., Porto; Godinho sculp. - [Porto: na Officina de António Alvares Ribeiro, 1789] [cópia digital disponível em http://purl.pt/4036]

Vista da cidade do Porto, desde a Torre de Marca até as Fontainhas / [M. M.] Aguilar delin. e exculp. no anno de 1791. [cópia digital disponível em http://purl.pt/13546]

Planta da cidade do Porto contendo o palácio de Christal, nova alfândega, e diversos melhoramentos posteriores a 1844 / por F. Perry Vidal; Emygdio, gr. - Escala [ca 1:66oo], 4000 Palmos $=[13,30 \mathrm{~cm}] .-$ Lisboa: Off. de Vasques \& c ca ., 1865 [cópia digital disponível em http://purl.pt/3556]

Alinhamento da Rua da Vitória (...) - 1851, por Joaquim da Costa Lima Júnior (Arquivo Histórico Municipal do Porto) [cópia digital disponível em http://gisaweb.cm-porto.pt/ units-of-description/documents/335656/]

Alinhamento na Rua da Vitória e Viela de São Roque até às Taipas (...) - 1851, por Joaquim da Costa Lima Júnior (Arquivo Histórico Municipal do Porto) [cópia digital disponível em http://gisaweb.cm-porto.pt/units-of-description/ documents/335635/]

Arquivo Distrital do Porto, Cabido, 5399, fls. $214 \mathrm{v}^{\mathbf{0}}-216 \mathrm{v}^{\mathrm{o}}$. Apud AFONSO, José Ferrão - A rua das Flores no século XVI. Elementos para a história urbana do Porto quinhentista. Porto: F.A.U.P, 2001, pp. 265-266.

Planta topográfica da cidade do Porto: quadrícula 258 / 1880 - [1892], escala 1:500, levantada sob direção de Augusto Gerardo Teles Ferreira [cópia digital disponível em http://gisaweb.cm-porto.pt/units-of-description/documents/519579/]

Vista aérea da baixa do Porto, 1930 [consultada em http:// portoarc.blogspot.com/2015/o7/governo-politico-v. htmlFICHA]

Fotografia aérea da cidade do Porto: 1939-1940: fiada 18, n. 347 (Arquivo Histórico Municipal do Porto) [cópia digital disponível em http://gisaweb.cm-porto.pt/units-ofdescription/documents/587801/]

Carta Militar de Portugal, folha 365 Escala 1/25 ooo, Serviço Cartográfico do Exército. 


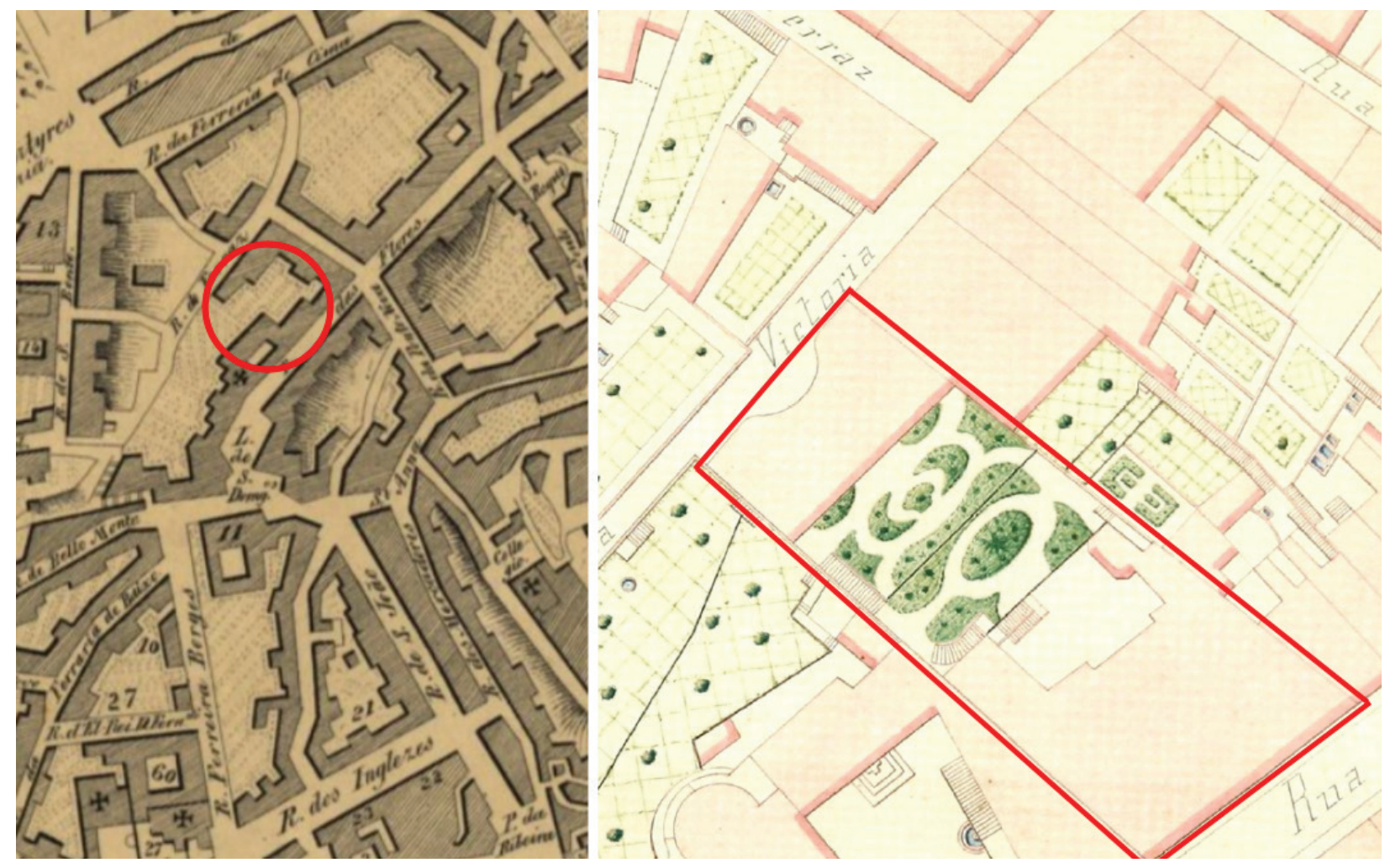

Figura 1 - Localização do palácio em extracto da Planta de Perry Vidal (1844) e do Levantamento de Teles Ferreira de (1880/92).
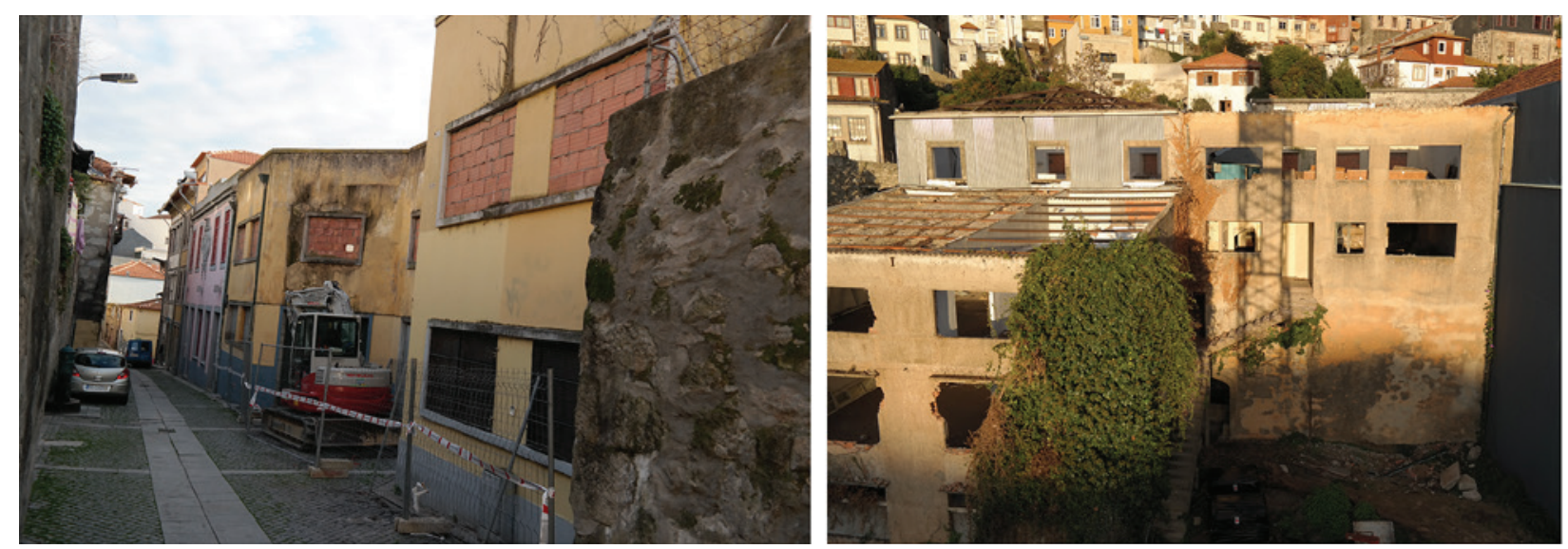

Figura 2 - Vistas da fachada e do alçado tardoz do edifício sito na Rua da Vitória. 

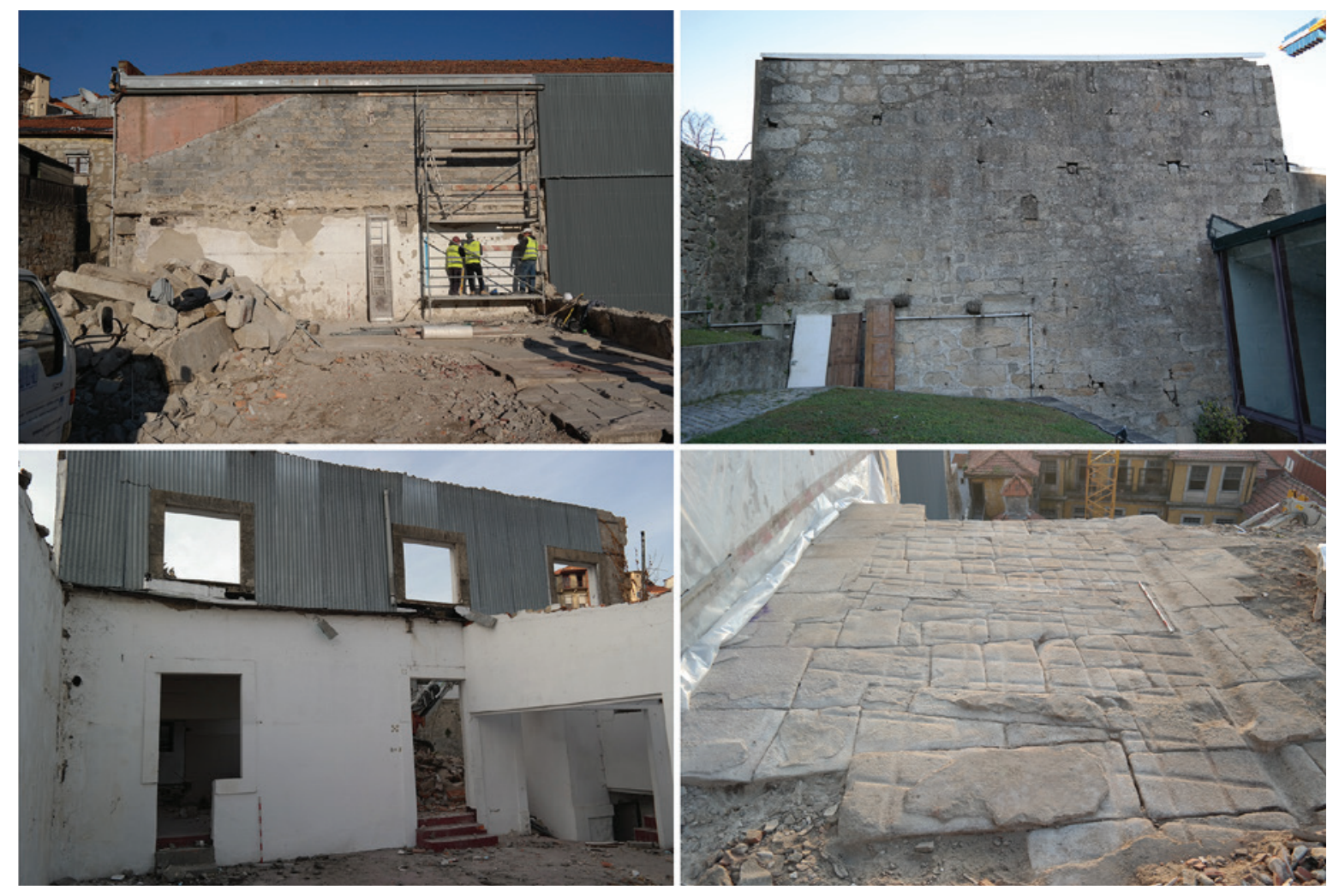

Figura 3 - Vistas dos negativos nas paredes nascente e poente do edifício, das janelas reaproveitadas e do piso lajeado da cocheira.
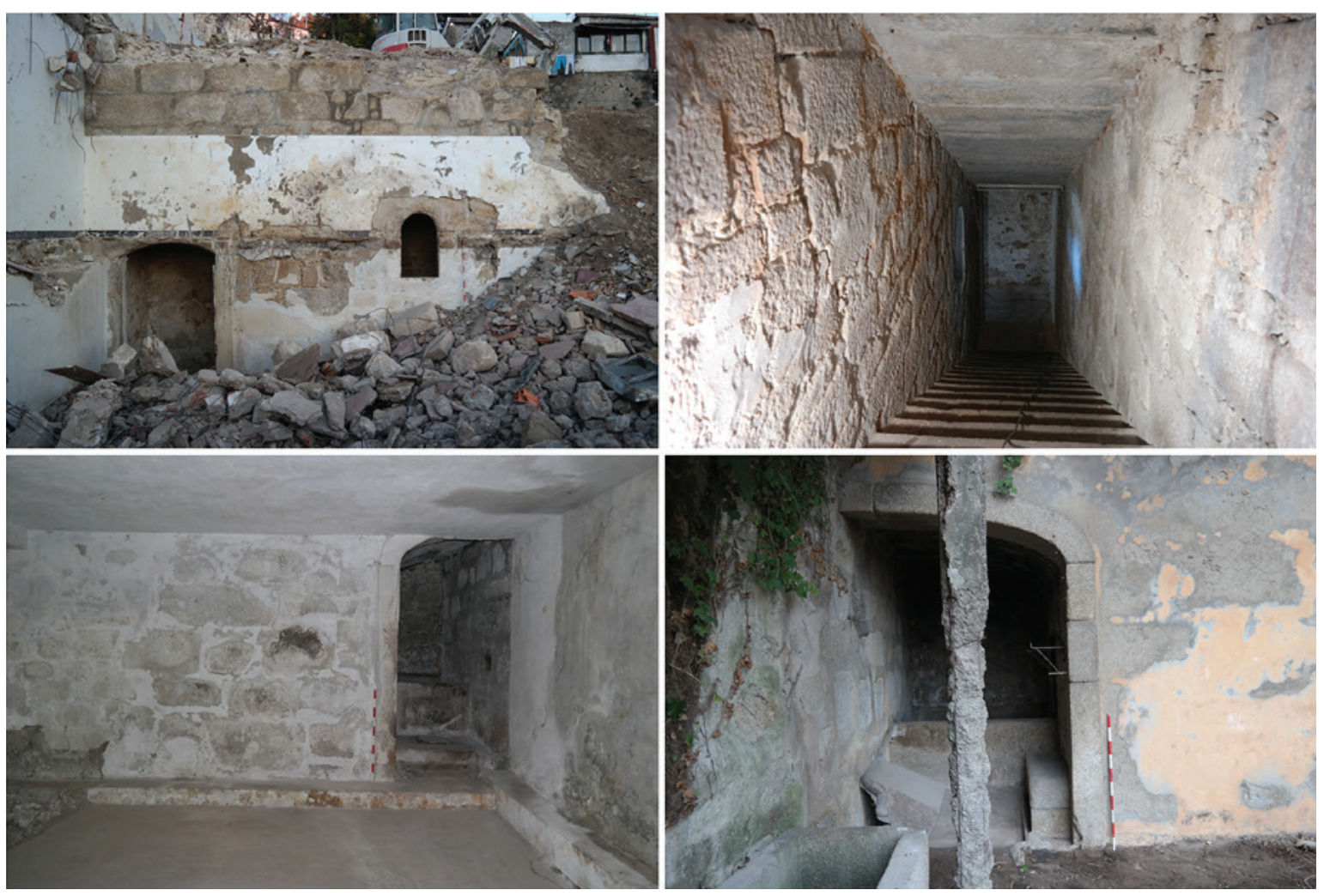

Figura 4 - Vistas do alçado tardoz da cocheira com a porta e janela, da escadaria interior e das duas partes que constituem a fonte. 


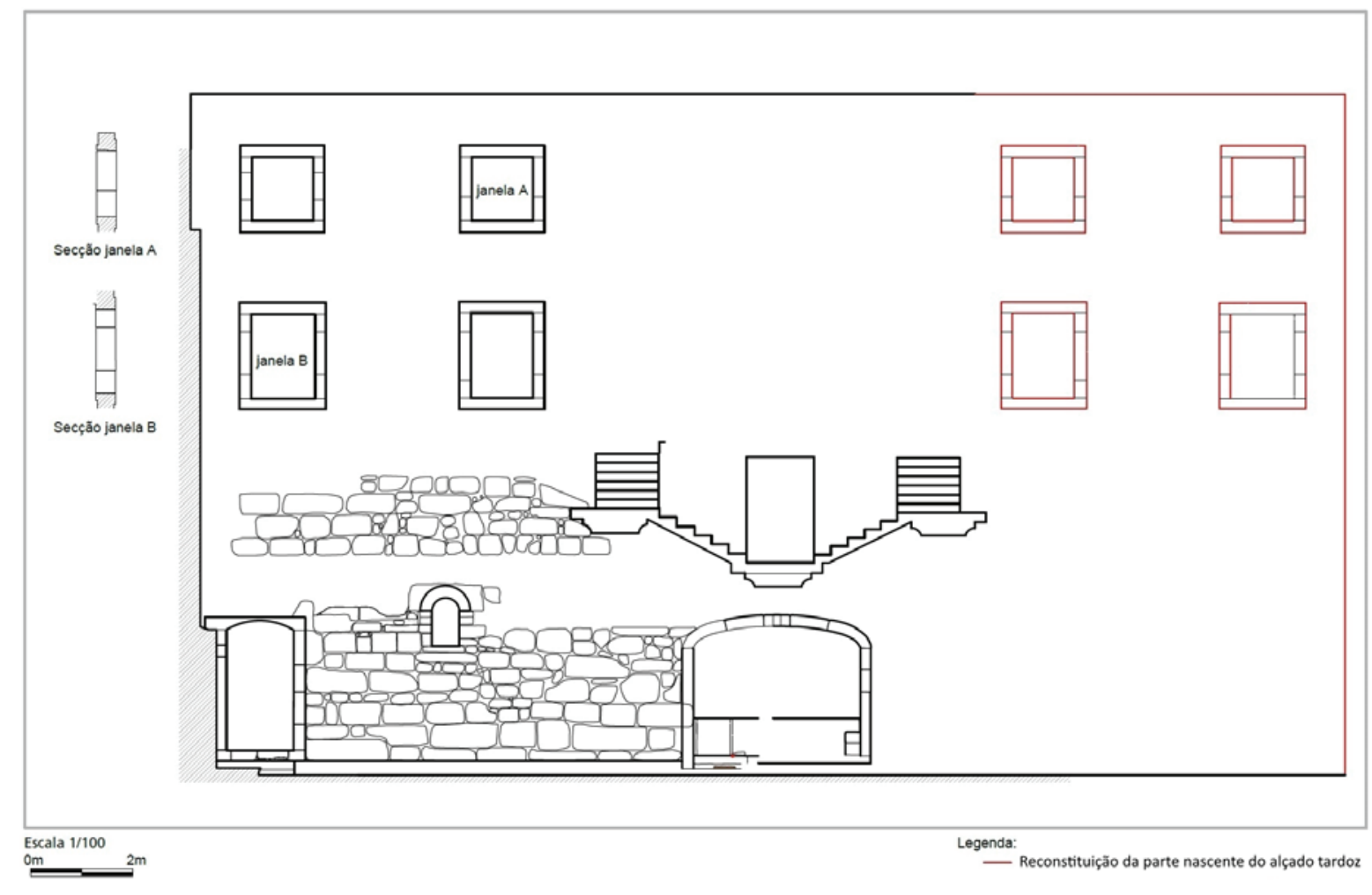

Figura 5- Reconstituição do alçado tardoz da cocheira.

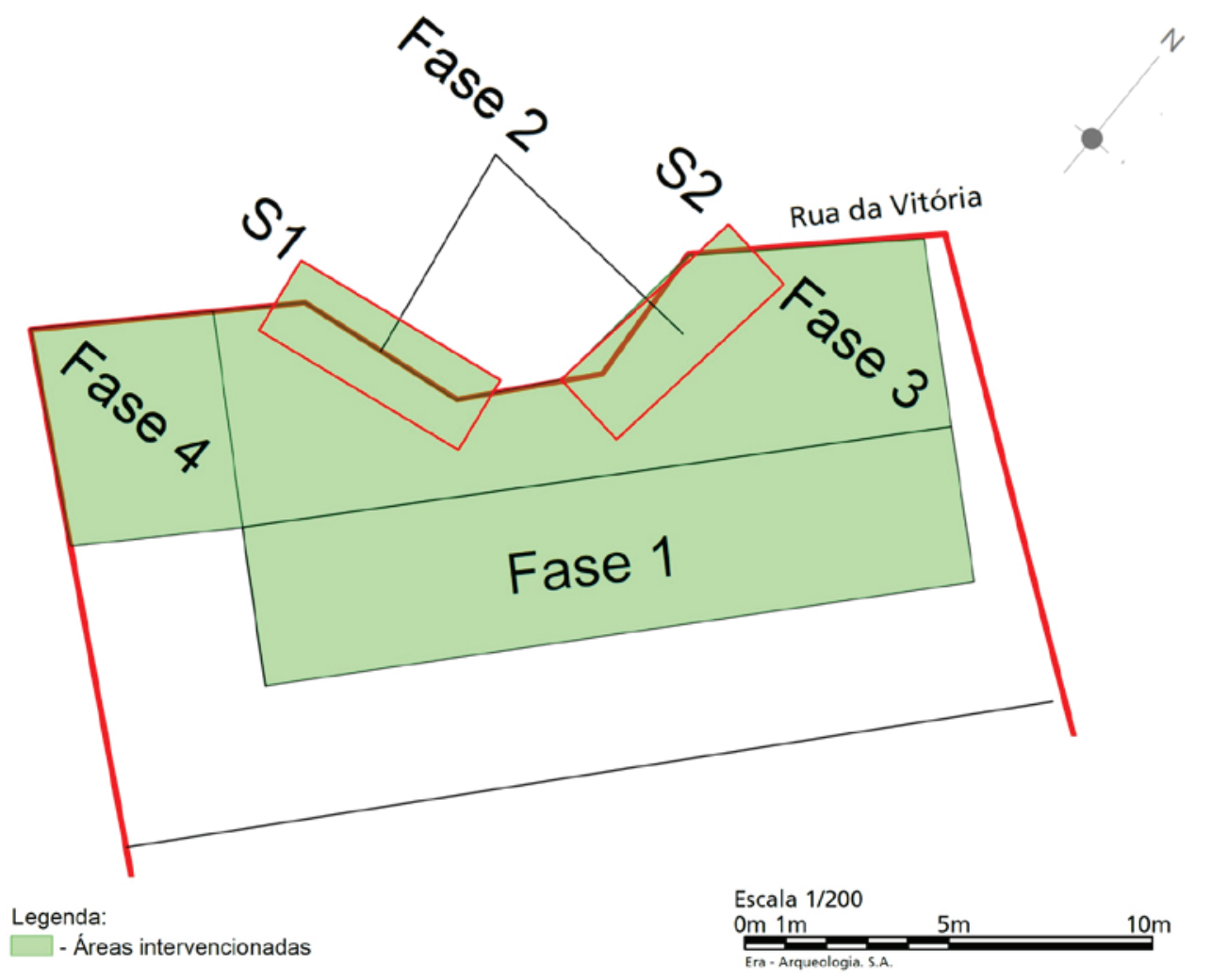

Figura 6 - Esquema das várias fases intervencionadas durante as várias fases de escavação. 


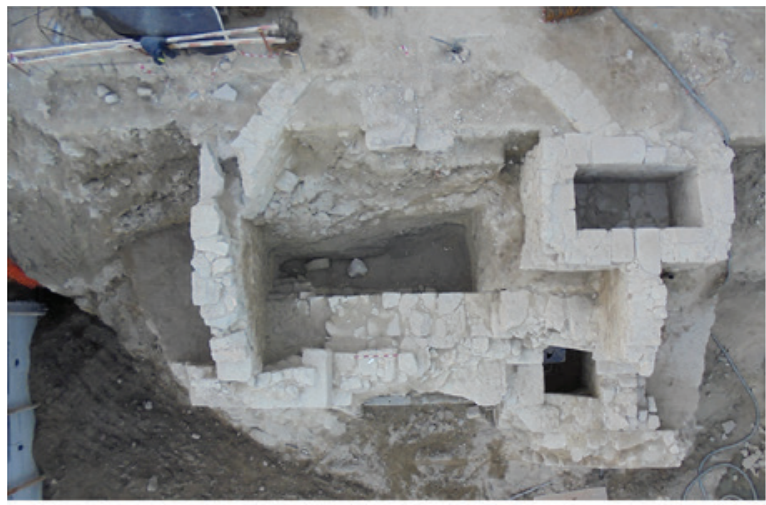

Fase 1

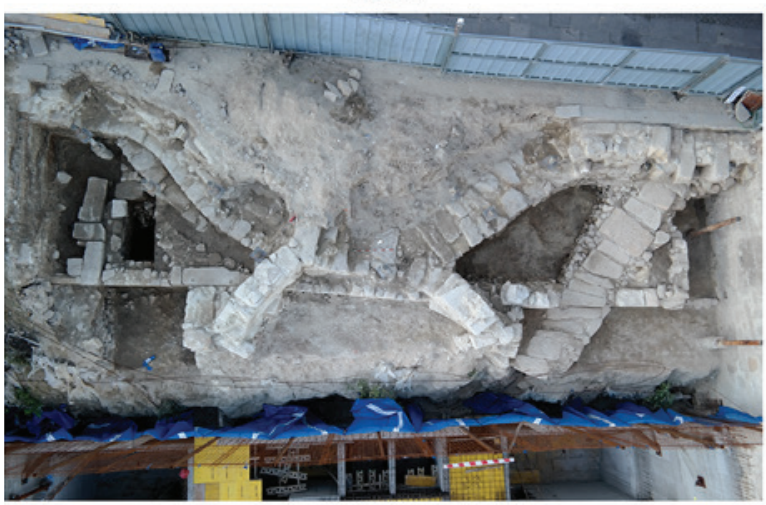

Fase 3

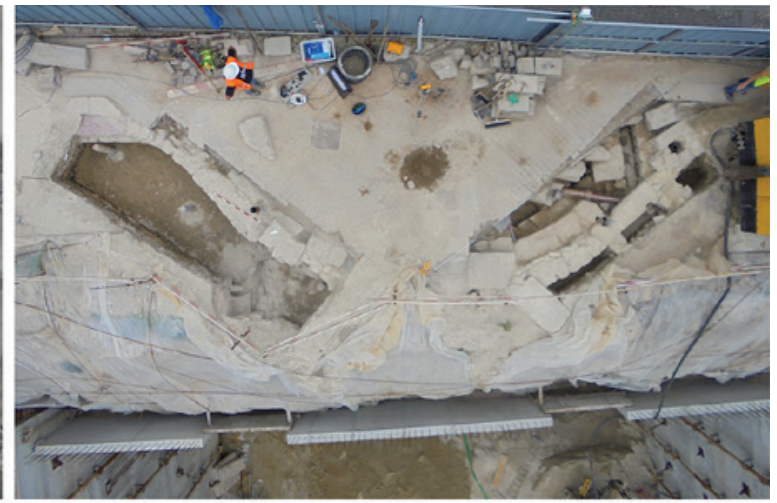

Fase 2

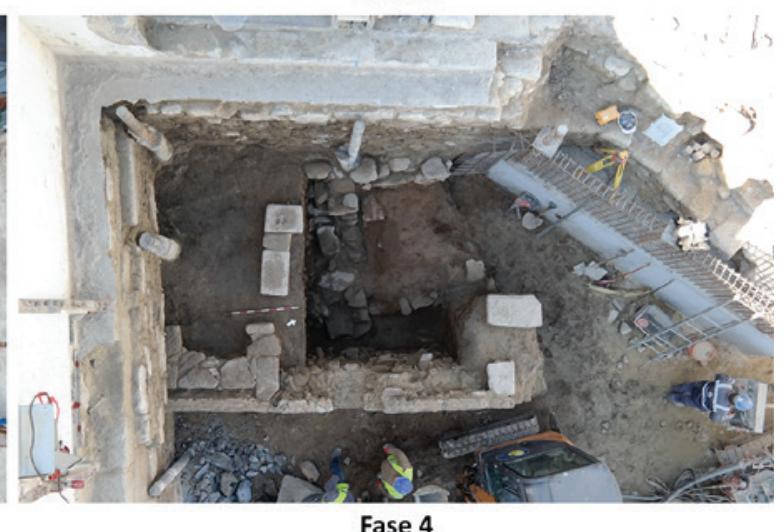

Figura 7 - Vistas dos planos finais das quatro fases de escavação arqueológica.

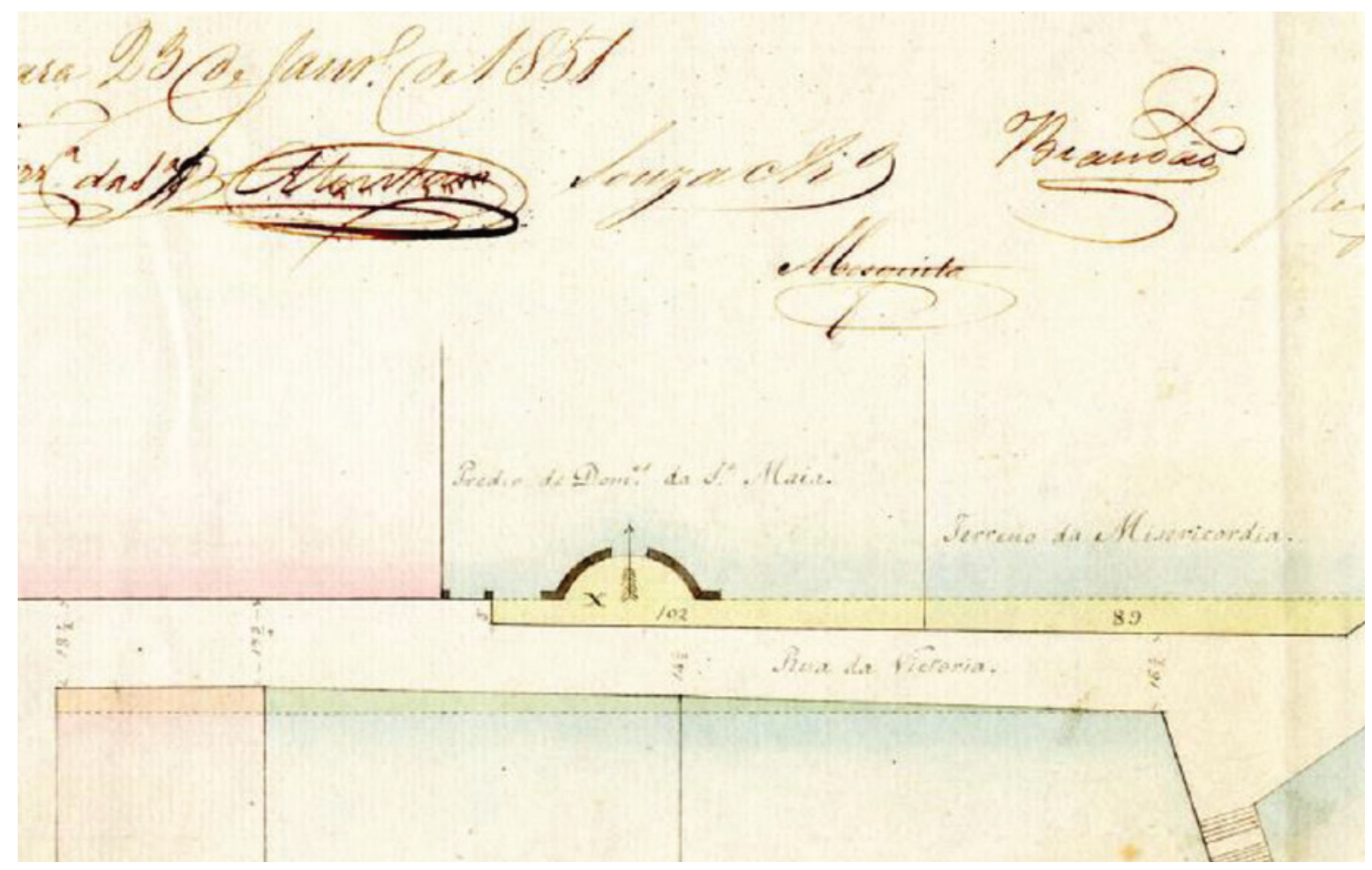

Figura 8 - Extrato do alinhamento da Rua da Vitória pelo Arquitecto Joaquim da Costa Lima Júnior, datada de 23 de Janeiro de 1951. 


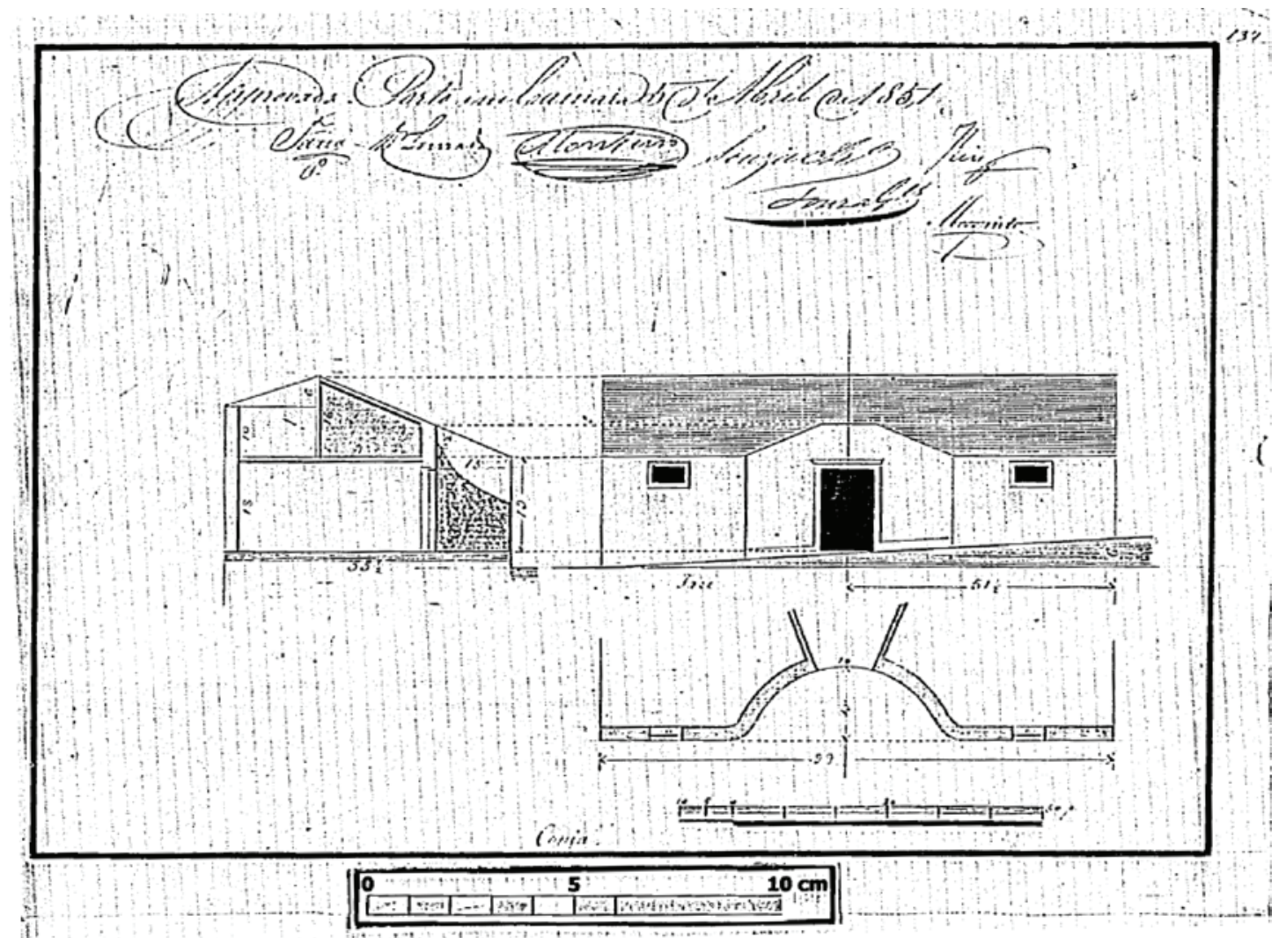

Figura 9 - Planta da cocheira projectada por Domingos de Oliveira Maia (AFONSO, 2008).

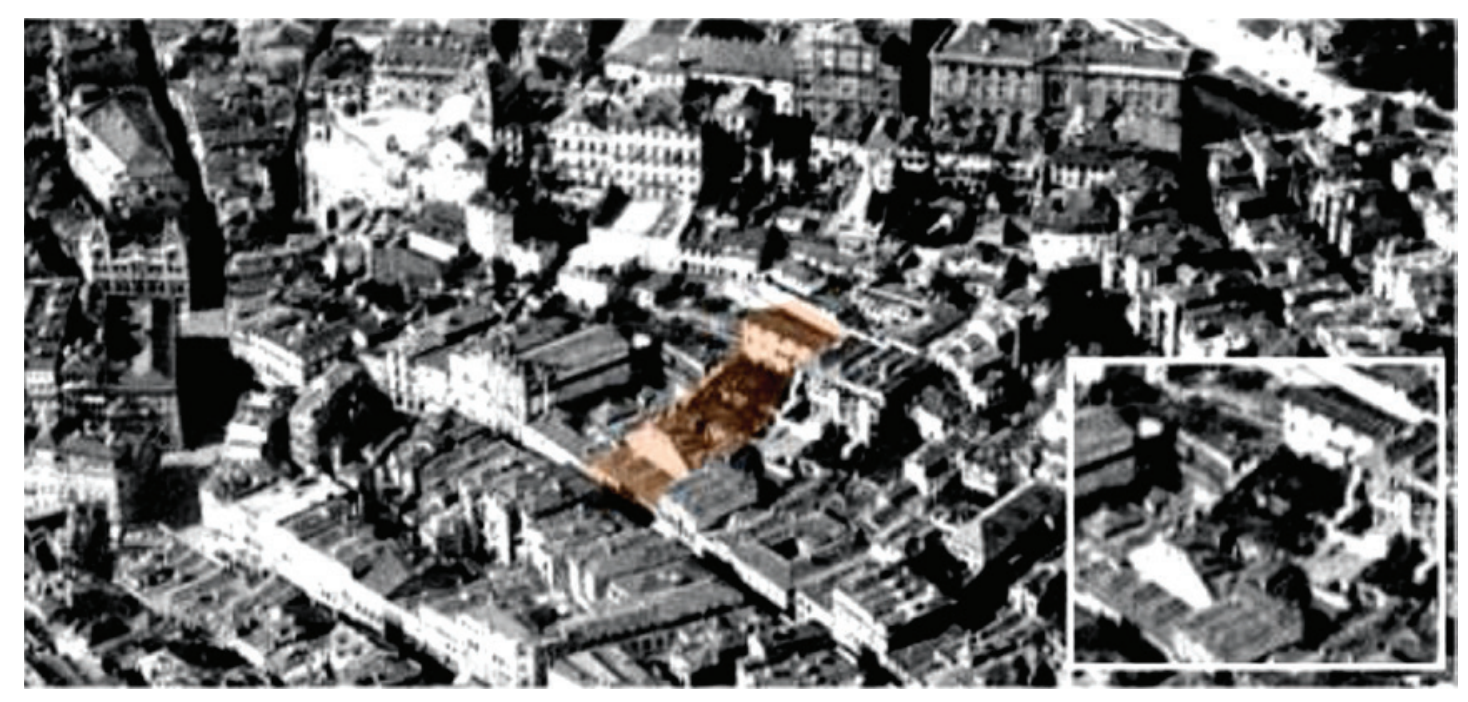

Figura 10 - Palácio e Cocheira - Adaptado da foto aérea da baixa do Porto, 1930 (Foto Beleza). 


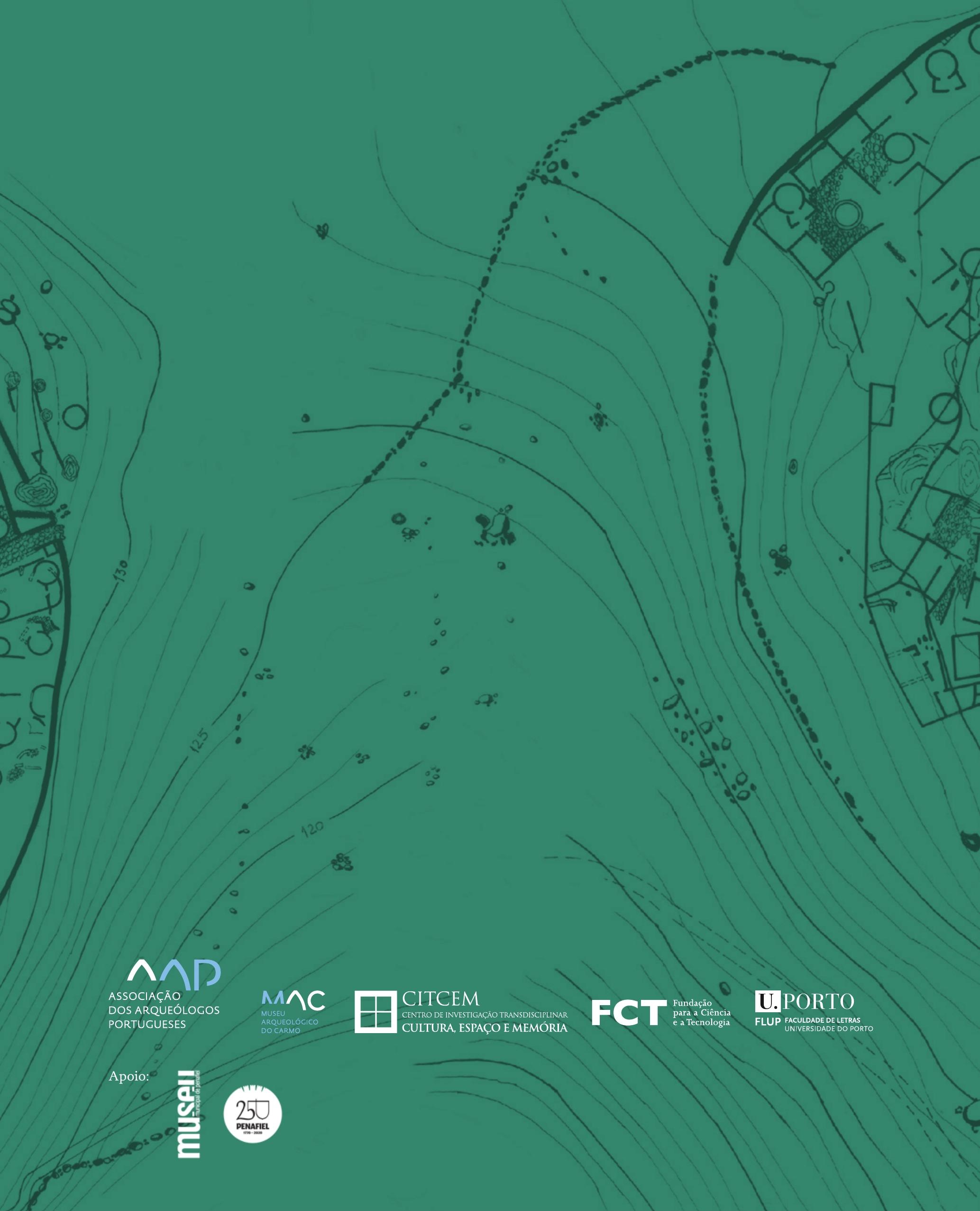

